FILOLOGIJA 76, Zagreb 2021.

UDK 373.3.016.013:81'272

DOI https://dx.doi.org/10.21857/y26kec4j89

Izvorni znanstveni članak

Rukopis primljen 22. III. 2021.

Prihvaćen za tisak 26. V. 2021.

Lucija Šimičić

Sveučilište u Zadru

Odjel za lingvistiku

Trg kneza Višeslava 9, HR-23000 Zadar

lsimicic@unizd.hr

Marija Ćubelić

VII. gimnazija, Zagreb

Križanićeva 4, HR-10000 Zagreb

mcubelic5@gmail.com

\title{
IZMEĐU STANDARDNOG VARIJETETA I LOKALNIH GOVORA: JEZIČNE PRAKSE OSNOVNOŠKOLACA U MAKARSKOM PRIMORJU $^{1}$
}

U hrvatskom obrazovnom kontekstu poseban izazov predstavlja poučavanje hrvatskog standardnog varijeteta $u$ neštokavskim sredinama $u$ kojima se od djece očekuje ili ovladavanje dvama kodovima ili postupno prelaženje sa zavičajnog na standardni kod koji je od zavičajnoga nerijetko i vrlo udaljen na strukturnoj razini. Polazeći od ideje da jezičnu politiku čine jezične ideologije, prakse i upravljanje jezikom (Spolsky 2004, 2009), cilj je rada analizirati jezične prakse osnovnoškolaca u Makarskom primorju u formalnim i neformalnim domenama, posebno u školi i izvan nje, te utvrditi način na koji su jezične prakse povezane sa stavovima prema standardnom varijetetu i lokalnim govorima, odnosno koje su dominantne ideologije koje su makarski osnovnoškolci internalizirali i koje utječu na njihov stav prema lokalnom govoru, učestalost i kontekste njegove uporabe. Analiza jezičnih praksi osnovnoškolaca temelji se na materijalu prikupljenom tijekom terenskog istraživanja provedenog 2018. i 2019. godine u Makarskome primorju. Dio podataka prikupljen je sociolingvističkim upitnikom,

1 Rad je nastao na temelju rezultata istraživanja u sklopu projekta Govori Makarskog primorja: dijakronija i sinkronija koji financira Hrvatska zaklada za znanost. 
Lucija Šimičić, Marija Ćubelić: Između standardnog varijeteta i lokalnih govora...

FILOLOGIJA 76(2021), 201-251

a dio etnografskim istraživanjem koje je uključivalo i intervjuiranje nastavnika kao ključnih dionika u procesu upravljanja jezikom na lokalnoj razini.

\section{Uvod}

Jezične promjene pojedine segmente neke jezične ili govorne zajednice zahvaćaju nejednakim intenzitetom, a posljedice se ovih promjena u različitim dijelovima određenog jezičnog prostora manifestiraju na različite načine. U nekim slučajevima jezična promjena podrazumijeva preoblikovanje strukture lokalnog jezičnog koda, dok u drugima i zamjenu jezika nekim drugim, u širem društvu obično, dominantnijim kodom (usp. Dorian 1981, Hill-Hill 1986, Sasse 1992, Škevin Rajko-Šimičić 2019 itd.). Iako ne uvijek presudna, uloga obveznog formalnog obrazovanja i u jednom i u drugom tipu procesa često je izražena. Odgojno-obrazovne ustanove, uključujući vrtiće i osnovne škole, uz obitelj i vršnjačke grupe, neka su od ključnih mjesta oblikovanja jezičnih praksi kao i usađivanja određenih jezičnih ideologija od malih nogu, pa je i njihov udio odgovornosti za očuvanje jezične raznolikosti neosporan.

U hrvatskom obrazovnom kontekstu poseban izazov predstavlja poučavanje hrvatskog standardnog varijeteta u neštokavskim sredinama u kojima se od djece očekuje ili ovladavanje dvama kodovima ili postupno prelaženje sa zavičajnog na standardni kod koji je od zavičajnoga nerijetko i vrlo udaljen na strukturnoj razini. U ranijim se istraživanjima manje pažnje pridavalo ulozi i očuvanju hrvatskom jezičnom standardu strukturno bliskih štokavskih varijeteta pa se u ovom radu bavimo upravo takvim kontekstima. Cilj je rada analizirati jezične prakse osnovnoškolaca $\mathrm{u}$ Makarskom primorju u formalnim i neformalnim domenama, posebno $u$ školi i izvan nje, te utvrditi način na koji su jezične prakse povezane sa stavovima prema standardnom varijetetu i lokalnim govorima, odnosno koje su dominantne ideologije koje su makarski osnovnoškolci internalizirali i koje utječu na njihov stav prema lokalnom govoru, tj. različitim nestandardnim varijetetima koji se rabe u lokalnom kontekstu, učestalosti i kontekstima njihove uporabe. Pritom je potrebno uzeti u obzir diskurse različitih dionika koji potencijalno utječu na govor mladih u ovoj regiji: roditelja i nastavnika (naročito nastavnika Hrvatskoga jezika) kao i prisutnost lokalnih govora u javnome prostoru (npr. u medijima, jezičnome krajoliku i sl.). Ovakva je analiza kompleksna jer ni osobe odgovorne za odgoj i obrazovanje, bilo da se radi o nastavnicima i/ili starijim čla- 
novima obitelji, nisu jedine koje oblikuju jezične politike na mikrorazini (u svojim obiteljima, razredima i sl.), već su i same pod utjecajem jezičnih politika koje niču iz nekada mnogo širih javnih diskursa, u njima se dodatno (re)konstruiraju, prenose na nove generacije i tako dalje promiču.

Od početaka sustavnog bavljenja jezičnom politikom u okvirima sociolingvistike do danas bitno se promijenilo shvaćanje što ona jest i što obuhvaća. Naime, ako je u ranoj fazi bila usmjerena uglavnom na iznalaženje rješenja na jezične probleme, i to prije svega na nacionalnoj razini (Jernudd i Das Gupta 1971, Fishman 1973) u državama formiranima nakon Drugog svjetskog rada ili uslijed dekolonizacije (Ricento 2000), s vremenom je postajalo sve jasnije da je nedostatno jezičnu politiku razmatrati isključivo kao jednosmjerno djelovanje odozgo. Naime, nacionalne jezične politike mogu podjednako biti pod utjecajem međunarodnih politika kao i pod utjecajem jezičnih stavova i jezičnog ponašanja samih govornika te njihov utjecaj nije moguće razumjeti isključivo analizom jezičnog planiranja kao ključnog vida jezične politike $\mathrm{u}$ tom ranom razdoblju. S vremenom se pokazalo da, osim upravljanja jezikom, odnosno svjesnog i otvorenog djelovanja usmjerenog na oblikovanje ili korigiranje jezičnog ponašanja i jezičnih vrijednosti, jezičnopolitičko djelovanje obuhvaća i jezične ideologije kao duboko ukorijenjena uvjerenja o vrijednosti pojedinih jezičnih obilježja ili čitavih jezičnih sustava, kao i konkretne jezične izbore i ponašanja, odnosno jezične prakse (Spolsky 2004). Zbog međusobne povezanosti triju navedenih komponenti analiza bi svake zasebno bila parcijalna, pa tek sagledavanje njihove ukupnosti omogućuje razumijevanje različitih faktora koji oblikuju jezičnu politiku u bilo kojem institucionalnom kontekstu, pa tako i obrazovnom. Upravo zato u radu analiziramo ne samo jezične prakse makarskih osnovnoškolaca već $i$ jezične stavove $i$ jezične ideologije na temelju kojih se uočeni stavovi oblikuju, te navodimo primjere kako se jezikom upravlja u razredu, ali i na široj nacionalnoj razini.

Unatoč ranijim shvaćanjima prema kojima se jezična politika izjednačavala isključivo sa službenim djelovanjem na makrorazini neke jezične zajednice, ponajviše države ili nacije, danas se motivi (ne)uspješnosti jezičnopolitičkog djelovanja na makrorazinama traže u analizi jezičnih praksi, jezičnih ideologija i upravljanja jezikom i na mikrorazinama, primjerice $u$ društvenim prostorima koje Fishman (1972) naziva funkcionalnim domenama kao što su obitelj, obrazovanje, javni mediji i sl. Imajući u vidu brojnost faktora i dionika koji sudjeluju i međusobno utječu jedni na druge $u$ kreiranju jezičnih politika kao i višestrukosti razina na kojima se one oblikuju, a koje Ricento i Hornberger (1996) metaforički uspoređuju sa slojevitošću glavice luka, sveobuhvatni prikaz jezične politike u osnovnoš- 
kolskom odgojno-obrazovnom kontekstu bio bi preširok. Ovaj je rad stoga nužno ograničen na analizu tek nekih vidova pojedinih komponenti jezične politike $\mathrm{u}$ jednom hrvatskom lokalnom kontekstu koje analiziramo na temelju podataka prikupljenih i sociolingvističkim upitnikom i dubinskim intervjuima s nastavnicima, ali ih razmatramo i u odnosu na službene jezičnopolitičke smjernice iskazane u relevantnim dokumentima na nacionalnoj razini.

Nakon uvodnog teorijskog dijela u kojem definiramo temeljne pojmove i koncepte na koje se oslanjamo prilikom analize, kontekstualiziramo ovo istraživanje u svjetlu dosadašnjih spoznaja o ulozi obrazovnog sustava u promicanju određenih jezičnih ideologija, kreiranju jezičnih stavova kao i oblikovanju jezičnih praksi. Slijede temeljna obilježja diskursa institucionalnog okvira kojim je definirana jezična politika u osnovnoškolskom odgoju i obrazovanju u RH, a zatim popis i opis osnovnih obilježja govorā Makarskoga primorja na temelju dosad objavljenih dijalektoloških radova o govorima toga područja. U metodološkom dijelu prikazujemo metode, kvantitativne i kvalitativne, korištene u procesu prikupljanja materijala tijekom terenskog rada te opisujemo uzorak sudionika istraživanja čije odgovore analiziramo u sljedećem dijelu rada. Nakon analize dijela podataka iz sociolingvističkog upitnika te za ovu analizu relevantnih dijelova intervjua s manjim brojem sugovornika, navodimo preliminarne zaključke o međusobnom utjecaju jezičnih praksi, jezičnih ideologija kao i upravljanja jezikom u osnovnoškolskom obrazovnom kontekstu.

\section{Teorijski okvir}

Jezična politika složen je društveno-kulturni proces kojim se oblikuju struktura, funkcija, uporaba i usvajanje jezika. Obuhvaća službeni jezičnopolitički okvir obično u vidu pisanih dokumenata kojima se reguliraju jezična pitanja, neslužbene i često prikrivene mehanizme koji utječu na jezično ponašanje i uvjerenja o jeziku te mogu i ne moraju biti u skladu s navedenim službenim okvirom, kao i sve instance javnopolitičkog diskursa koji utječe na jezičnu strukturu i djelovanje, uključujući njihovu interpretaciju i prisvajanje u specifičnim kontekstima u kojima se jezične politike realiziraju (Johnson 2013:9).

Iz navedene definicije proizlazi da proučavanje jezične politike zahtijeva interdisciplinarnost (Ricento 2006) te da je jezična politika nužno višeslojna jer se odvija na više razina (Kaplan-Baldauf 1997, Schiffman 1996, Shohamy 2006, Hornberger-Johnson 2007, Johnson 2013, Skelin Horvat-Šimičić 2017, Tollefson-Pérez-Milans 2018, Śimičić 2019 itd.), iako nije uvijek 
jednostavno odrediti granicu između makrorazine i mikrorazine kao ni između jezične politike "odozgo" i one "odozdo". U odgojno-obrazovnom kontekstu višeslojnost jezične politike očituje se, na primjer, u činjenici da jezična politika neke regije (ili županije ako govorimo o prostoru $\mathrm{RH})$, pa čak i određene škole, predstavlja mikrorazinu djelovanja u odnosu na nacionalnu jezičnu politiku u obrazovanju, ali makrorazinu u odnosu na jezičnu politiku koju određeni nastavnik provodi u svom razredu. Jedan od važnih uvida ovakvog interdisciplinarnog i slojevitog pristupa analizi jezičnih politika jest i spoznaja o napetostima između diskursa prisutnih u jezičnom upravljanju na makrorazini i jezičnih praksi u mikrokontekstima kao i između šire društvene strukture i djelatne uloge pojedin(a)ca ključnih za razumijevanje jezične politike i planiranja jezika (Bouchard-Glasgow 2019, Glasgow-Bouchard 2019). Svim je realiziranim oblicima jezičnih politika zajedničko to što podrazumijevaju moć i autoritet pojedinca ili grupe $u$ razgraničavanju legitimnog od nelegitimnog u jeziku samom i jezičnim praksama (usp. McCarty 2011, Starčević-Kapović-Sarić 2019) bilo da su oni unaprijed regulirani ili da proizlaze iz interakcije te da na taj način potencijalno promiču asimetriju u odnosima moći (McCarty 2011).

Jezične prakse neraskidivo su povezane s jezičnom politikom. Dok ih neki autori, primjerice Spolsky (2004), smatraju sastavnim dijelom jezične politike, drugi ih tumače kao posljedicu jezičnopolitičkog djelovanja (npr. Schiffman 1996). Iako jezične prakse mogu biti pojedinačne i zajedničke, u radu ih sagledavamo na mikrorazini pojedinaca, osnovnoškolskih učenika u Makarskom primorju. Varijeteti koje ti pojedinci upotrebljavaju dijelom su njihovih jezičnih repertoara koje definiramo kao ukupnost svih jezičnih resursa kojima vladaju i iz kojih crpe sredstva za izražavanje i iskazivanje identitetâ u interakciji (Duranti 1997, Lüdi Py 2009, Snell 2013, Busch 2012, 2017). Jezični repertoari stoga istovremeno pripadaju zajednici u kojoj su različiti varijeteti i načini izražavanja prepoznati kao legitimni komunikacijski kodovi (Gumperz 1964:137), ali su i individualni jer odražavaju »različite dimenzije osobne povijesti, iskustva i okoline, stavove, uvjerenja i ideologije, kognitivne i fizičke sposobnosti« višejezičnog govornika (Wei 2011:1223). Za potrebe ovog rada analiziramo ponajviše one dijelove jezičnih repertoara koji se odnose na poznavanje različitih varijeteta hrvatskog jezika, osobito govorā Makarskog primorja i standardnog varijeteta hrvatskog jezika. Jezični su repertoari pojedinaca iz kojih potencijalno crpe elemente u svakodnevnim komunikacijskim praksama dakako mnogo opsežniji od dijela kojim se bavimo u ovome radu, no samo se izuzetno osvrćemo i na neke njihove aspekte koji izlaze iz okvira 
koji smo prethodno definirale (npr. dijelovi repertoara sudionika $u$ istraživanju koji se odnose na aktivno i/ili pasivno poznavanje nehrvatskih jezičnih resursa).

Bez obzira na to smatramo li jezične prakse jedinim od ishoda jezične politike ili njenim sastavnim dijelom, neodvojive su od jezičnih stavova i uvjerenja o jeziku koji pak proizlaze iz jezičnih ideologija (npr. Schiffman 1996, McCarty 2011). Jezične su ideologije često prešutne, u nekom društvu raširene, rano usvojene i zato duboko ukorijenjene zamisli o tome što jezik jest, kako funkcionira, što u njemu jest ili nije ispravno (usp. Woolard 1998, Blommaert 1999, McCarty 2011) te nerijetko podrazumijevaju uvjerenje o postojanju samo jednoga »ispravnoga«, a time često »boljega«i/ili »vrjednijega « jezičnoga oblika koji predstavlja određeni jezik (Starčević 2016) ili o neupitnoj vrijednosti nekog vida jezične stvarnosti (npr. jednojezičnosti ili višejezičnosti, jezičnoj raznolikosti i sl.).

\section{Utjecaj odgojno-obrazovnog sustava na jezične stavove i prakse}

U ovome se dijelu osvrćemo na ranija istraživanja položaja nestandardnih varijeteta u obrazovnom procesu, kao i na službeno definiranu jezičnu politiku u hrvatskom odgojno-obrazovnom kontekstu.

3.1. Prijašnja istraživanja mjesta nestandardnih varijeteta u odgojnoobrazovnom procesu

Zanimanje za položaj i ulogu nestandardnih varijeteta u odgojno-obrazovnom sustavu postepeno se razvijalo od početnoga bavljenja povezanošću učenikova jezika i školskoga uspjeha do proučavanja mogućnosti i dobrobiti uvođenja u učionice nestandardnoga varijeteta kao jednoga od jezika poučavanja. Nakon prvotnih hipoteza o tzv. jezičnom deficitu kod djece radničke klase, u okvirima sociolingvistike nestandardni su se varijeteti sve više počeli sagledavati u svjetlu jezične različitosti, pogledu prema kojemu su oni logično uređeni i jednakovrijedni sustavi kao i standardni varijeteti, iako se rabe $u$ drugačijim društvenim kontekstima i mogu imati drugačije komunikacijske funkcije (Labov 1969, Trudgill 1975, Cheshire i sur. 1989). Danas se oba ova pristupa smatraju ograničavajućima u razumijevanju jezične stvarnosti učenika te se pojam jezičnog repertoara kao skupa sredstava kojima govornik (učenik) raspolaže smatra u tom smislu prikladnijim (Snell 2013:115).

Učenici pritom oko desete godine postaju svjesni društvene vrijednosti nestandardnoga varijeteta i njegove prikladne uporabe u pojedinim si- 
Lucija Šimičić, Marija Ćubelić: Između standardnog varijeteta i lokalnih govora...

FILOLOGIJA 76(2021), 201-251

tuacijama, ali nakon toga sve manje koriste nestandardne oblike (Van De Craen-Humblet 1989). Pokazalo se, ipak, da nestandardni varijetet (lokalni varijetet, lokalni govor, mjesni govor, zavičajni govor), tj. jezik doma učenika, uz standardni varijetet $\mathrm{u}$ školama pozitivno utječe na kognitivni i afektivni razvoj djece (James 1996). Ako se u učionicama koristi i mjesni varijetet, učenici uče uspješno se služiti njime i standardnim varijetetom te lakše usvajaju nastavne sadržaje pa tako i druge strane jezike, pri čemu razvijaju samopoštovanje, cijene vlastite kulturne vrijednosti, a razvijaju i interkulturalnu kompetenciju (Težak 1996, Pavličević-Franić-Aladrović Slovaček 2017, James 1996, Yiakoumetti 2007 i dr.).

Uloga nestandardnih varijeteta $u$ formalnom obrazovanju u RH sagledava se uglavnom u kontekstu poštivanja načela zavičajnosti na nastavi Hrvatskoga jezika (Peruško 1961, Gudelj-Velaga 1990, Težak 1996 itd.). Težak zagovara kontrastivni pristup koji neprestano ima svoje predstavnike (usp. Težak 1996, Kapović 2006, Blažeka 2008, Puljak 2011), a u kojemu nastavnik koristi učenikov govor da učeniku ukaže na razlike između mjesnoga i standardnoga varijeteta kako bi učeniku usvojen i poznat varijetet pomogao pri usvajanju standardnoga uz daljnje uspješno komuniciranje na mjesnom varijetetu. $U$ današnje vrijeme, pak, djeci na početku institucionaliziranoga odgoja i obrazovanja standardni varijetet nije potpuno nepoznat i zahtjev za nastavom od poznatoga $\mathrm{k}$ nepoznatom mijenja se u korist hrvatskoga standardnog varijeteta (Blažeka 2008:272). Uz kontrastivni pristup naglašava se važnost komunikacijsko-funkcionalnoga i korelacijsko-integracijskoga pristupa (Pavličević-Franić-Aladrović Slovaček 2017, usp. i Težak 1996 i dr.) s ciljem razvoja komunikacijske kompetencije i omogućavanja učenicima da povezuju spoznaje te suvereno primjenjuju naučeno. Osim toga, hrvatski je jezik materinski jezik hrvatskim učenicima koji, ovladavajući njegovim nestandardnim varijetetima i standardnim varijetetom, postaju okomito dvojezični (usp. Težak 1996:407, Pavličević-Franić 2005:63-64) pa su okomita dvojezičnost i komunikacijska kompetencija također neki od ključnih koncepata u proučavanju uloge nestandardnih varijeteta u nastavi. Dosad se pokazalo da se hrvatski učenici uglavnom bolje snalaze rješavajući zadatke i pokazujući teorijsko znanje o jeziku (lingvistička kompetencija) nego što primjenjuju jezično znanje $u$ konkretnim kontekstima (komunikacijska kompetencija) čime bi se očitovali kao uistinu kompetentni govornici hrvatskoga jezika (Listeš-Grubišić Belina 2016, Pavličević-Franić-Aladrović Slovaček 2017).

Istraživanje stavova nastavnika i učenika o nestandardnim varijetetima u nastavi i izvan odgojno-obrazovnoga procesa predstavlja još jedan smjer zanimanja u ovome području (Šimičić-Sujoldžić 2004, Turza-Bog- 
dan 2009, Nemeth-Jajić-Prvulović 2012, Sujoldžić-Šimičić 2013). Pozitivan stav i prema svom (mjesnom, zavičajnom) varijetetu i prema standardnome varijetetu, uz svijest o postojanju standardnoga varijeteta te razlikama među varijetetima, utječe na lakše ovladavanje standardnim varijetetom $u$ školi (Alerić-Gazdić-Alerić 2009). Nestandardni varijeteti sve se brže mijenjaju pod utjecajem mnogih unutarnjih i vanjskih čimbenika, no kao što Težak naglašava da se ne smije podcjenjivati ni precjenjivati vlastitu kulturu (1996:413), tako i u recentnoj literaturi nalazimo da treba promicati mjesne varijetete $u$ nastavi Hrvatskoga jezika, posebice $u$ jezičnom predmetnom području, »u kontekstu hrvatskoga jezika u cjelini« (Vulić 2015:80), pri čemu se uvažava i standard.

\subsection{Službena jezična politika u hrvatskom odgojno-obrazovnom kontekstu}

Jezična obrazovna politika odozgo u Republici Hrvatskoj tijekom godina doživljavala je promjene koje su u školama ravnatelji i nastavnici implementirali na različite načine. $U$ posljednjim važećim dokumentima ističe se usmjerenost na obrazovna postignuća, odnosno odgojno-obrazovne ishode, potiče uvođenje suvremenih nastavnih metoda, sredstava i oblika rada, ali i u pristupu poučavanju o nestandardnim varijetetima dolazi do promjena.

U dokumentima se uočavaju Težakove odrednice svrhe nastave hrvatskoga jezika: »... spoznaja o biti, osnovama i značajkama hrvatskoga jezika; svijest o potrebi učenja i njegovanja hrvatskoga jezika; pravilna uporaba književnoga, odnosno standardnoga hrvatskoga jezika u govorenju i pisanju « (Težak 1996:31). Prema još uvijek važećem Nastavnom planu i programu za osnovnu školu (MZOŠ 2006) koji je potekao iz Hrvatskog nacionalnog obrazovnog standarda (HNOS) (MZOŠ 2005), a koji će s vremenom zamjenjivati novi dokumenti, kao temeljni cilj nastave predmeta Hrvatski jezik navodi se osposobljavanje učenika za jezičnu komunikaciju pomoću koje će moći svladavati sadržaje svih predmeta u školi i pripremiti se za cjeloživotno učenje s naglaskom na ovladavanju standardnim jezikom kao preduvjetom za ostvarivanje predviđene svrhe i zadaća (MZOŠ 2006). Zadaće nastave jezičnoga predmetnoga područja uključuju osposobljavanje učenika za svakodnevnu komunikaciju, razvijanje svijesti o potrebi jezičnoga znanja, a usto se još navodi kako je nužno »suzbijanje straha od jezika; osvješćivanje razlika između standardnoga jezika i zavičajnih idioma; postupno usvajanje hrvatskoga jezičnog standarda « (MZOŠ 2006:25). Iako je istaknuto uočavanje razlika između varijeteta i postupnost u usvajanju standarda, učenje o nestandardnim varijetetima zakonski je predviđeno 
tek u 4. razredu kad se očekuje da će učenici nakon jezične teme Književni jezik i zavičajni govor moći »razlikovati književni jezik od zavičajnoga govora; odrediti svoj zavičajni govor u odnosu na jedno od tri narječja hrvatskoga jezika; usmeno i pisano komunicirati na svome zavičajnome govoru« (MZOŠ 2006:33).

Učenike se osvještava o razlikama između njihova varijeteta i hrvatskoga standardnoga varijeteta te ostalih varijeteta od 4 . razreda pri čemu nije vidljivo koliko se tada govori o obilježjima svih narječja, a koliko o narječju kojemu pripada varijetet zajednice u kojoj je pojedina škola. Premda se jasno potiče komunikacija na nestandardnome varijetetu, nije jasno do koje se mjere potiče pozitivan stav prema varijetetima prije 4 . razreda. Do tada je propisano samo da učenici nauče poštovati pravopisnu normu pri pisanju naziva iz učenikova zavičaja, a potom su u višim razredima za svaki razred navedene odrednice o nestandardnim varijetetima u obveznim i izbornim sadržajima. Daljnjim osvrtom na obvezne sadržaje u 5. razredu u predmetnom području hrvatski jezik nalazimo temu Hrvatski jezik-prošlost $i$ sadašnjost kojom se nastoji obuhvatiti tema jezične raznolikosti hrvatskoga jezika. U obrazovnim postignućima spomenute teme terminologija je ponešto drugačija od one za prethodni razred, pa se navodi da će učenici moći »razlikovati zavičajne idiome i književni jezik; osvijestiti postojanje različitih narodnih govora i potrebu njihova njegovanja; razvijati svijest o važnosti pravilnoga pisanja i govorenja hrvatskim književnim jezikom« (MZOŠ 2006:35). Nije pobliže određeno što sve podrazumijeva njegovanje nestandardnih varijeteta koji se, kao i standardni varijetet, u dokumentu javljaju pod različitim nazivima.

Sam pojam njegovanja, osim u Nastavnom planu i programu, čest je i u diskursu o kulturnoj baštini (usp. Zakon 1999). Neki nestandardni varijeteti imaju tako status nematerijalnoga kulturnoga dobra (Zakon 1999, Rješenje 2019) što može navesti na mišljenje da ih treba očuvati i zaštititi kao oblik iz prošlosti, no baština, posebice jezična, ne odnosi se samo na prošlost nego se u izvornoj i drugoj sredini njeguje i prenosi (Zakon 1999) s naraštaja na naraštaj, pri čemu se s vremenom i mijenja (Zakon 2005, Kirshenblatt-Gimblett 2013, Vokić 2015).

U 6. razredu u predmetnom području književnost govori se o dijalektnom pjesništvu pomoću ključnih pojmova »zavičajni motivi; čakavsko, kajkavsko i štokavsko pjesništvo« (MZOŠ 2006:41). U 7. razredu učenici osvješćuju »razliku između vlastitoga i književnoga naglasnoga sustava« (MZOŠ 2006:43) učeći o naglascima u hrvatskome jeziku. Jezično se izražavaju, među ostalim, tako što prevode pojedini zavičajni sinonim na stan- 
dardni jezik. ${ }^{2}$ Na popisu filmova nalaze se Smogovci i Tko pjeva, zlo ne misli u kojima se može čuti kajkavski varijetet, a roman Smogovci usto je dio obavezne lektire (MZOŠ 2006:44, 46). Općenito se u lektirnim naslovima i preporučenim filmskim ostvarajima može naići na nestandardne varijetete te je $\mathrm{u}$ 8. razredu također među obaveznom lektirom i filmovima navedeno djelo na kajkavskom - Breza (MZOŠ 2006:50). U 8. razredu najviše je sadržaja o nestandardnim varijetetima, od toga da učenici razlikuju »domaće (književne i dijalektne) i strane (potrebne i nepotrebne) riječi« (MZOŠ 2006:46), što se eksplicitno u dokumentu povezuje s osvještavanjem potrebe za njegovanim hrvatskim jezikom, potom da znaju koristiti zavičajne frazeme, zatim da u sklopu teme o refleksu jata savladaju prepoznavanje srodnih riječi s različitim refleksom u pojedinim hrvatskim narječjima do tema Osnovna obilježja hrvatskih narječja i Zavičajni govor i narječje prema književnome jeziku. Od učenika se očekuje da ponove sadržaje o varijetetima hrvatskoga jezika usvojene dotad te da razlikuju osnovna obilježja i prostore svih hrvatskih narječja, štokavsko narječje od hrvatskoga književnoga jezika, pa i nazive hrvatski književni jezik i hrvatski standardni jezik. Zavičajni govor i narječje stavljaju se u odnos prema standardu, učenici bi trebali i zamjenjivati riječi, izraze i rečenice jednoga varijeteta drugim, ali isto tako i osvijestiti da dijalektizmi i lokalizmi pripadaju isključivo razgovornom stilu. Očekuje se ipak da učenici slušaju, čitaju, govore i pišu dijalektne tekstove, a pri poučavanju o književnosti uči se o književnoj baštini uvažavanjem načela zavičajnosti (MZOŠ 2006:46-49). Tijekom osnovne škole definira se materinski jezik koji se spominje u kontekstu s drugim, službenim i manjinskim jezikom (MZOŠ 2006:35-36, 48).

Nacionalni okvirni kurikulum (MZOŠ 2011) dokument je kojim se posebno promiču znanje, solidarnost, identitet i odgovornost. Pojedinac u odgojno-obrazovnom sustavu izgrađuje osobni, kulturni i nacionalni identitet uz to što postaje i građaninom svijeta (MZOŠ 2011). Težnja za posebnošću i odmakom od globalnoga u suvremenom društvu zapravo pojedince i zajednice ne odmiče, već povezuje s globalizacijskim procesima (Kirshenblatt-Gimblett 2013, Nikočević 2012). Još se više ističe kompetencijski pristup pa tako i važnost komunikacijske kompetencije na materinskom jeziku (MZOŠ 2011). Kako bi sačuvao nacionalni identitet, prema tekstu NOK-a povezan s kulturom, društvenom, moralnom i duhovnom baštinom, pojedinac treba »čuvati i razvijati hrvatski jezik « pazeći »na njegovu pravilnu primjenu« (MZOŠ 2011:22). Hrvatski se jezik pritom u od-

2 Iako preferiramo govoriti o standardnom varijetetu kao jednom od varijeteta hrvatskoga jezika, termin standardni jezik termin je koji se rabi u navedenome dokumentu (MZOŠ 2006:44), pa ga ovdje tako i navodimo. 
Lucija Šimičić, Marija Ćubelić: Između standardnog varijeteta i lokalnih govora...

FILOLOGIJA 76(2021), 201-251

gojno-obrazovnim ciljevima opisuje kao bitan čimbenik hrvatskoga identiteta, a odmah se zatim naglašava i važnost sustavnoga njegovanja hrvatskoga standardnoga (književnoga) jezika ${ }^{3}$ (MZOŠ 2011:23).

U dokumentu Kurikulum nastavnog predmeta Hrvatski jezik za osnovne škole $i$ gimnazije glavnom svrhom učenja i poučavanja predmeta Hrvatski jezik smatra se »osposobljavanje učenika za jasno, točno i prikladno sporazumijevanje hrvatskim standardnim jezikom, usvajanje znanja o jeziku kao sustavu, slobodno izražavanje misli, osjećaja i stavova te spoznavanje vlastitoga, narodnog i nacionalnog jezično-kulturnog identiteta « (MZO 2019, dalje: Kurikulum za Hrvatski jezik; kurikul). Iako se u dokumentu govori o slojevitosti identiteta te potrebi »očuvanja hrvatskih dijalekata i govora« pa čak i mogućnosti stvaralačkog izražavanja na mjesnim govorima, dominantan diskurs naglašava zahtjeve za stjecanjem vještine odgovarajuće uporabe standardnoga jezika i za usvajanjem lingvističkoga znanja kao i »nužnosti uporabe hrvatskoga standardnog jezika i pravila kulturne komunikacije« (MZO 2019).

Navedeni kurikul (MZO 2019) recentan je dokument koji se počeo primjenjivati tek od šk. god. 2019./2020. pa nije relevantan za izjave naših ispitanika, no pokazuje smjer obrazovne jezične politike $u \mathrm{RH}$. Od 1. razreda u predmetnom području hrvatski jezik $i$ komunikacija navode se odgojno-obrazovni ishodi (znanja, vještine, stavovi i vrijednosti) povezani s uočavanjem razlika između standardnoga i vlastitoga nestandardnoga varijeteta, a nestandardni varijetet također je povezan sa svim jezičnim djelatnostima (MZO 2019). U tom kontekstu, već se u 1. razredu očekuje od učenika sposobnost razlikovanja mjesnog i standardnog varijeteta te se nastavnicima preporuča rad na očuvanju zavičajnih idioma - kulturnoga nasljeđa i postupanje u skladu s načelom zavičajnosti prema kojem učenicima treba dopuštati slobodno izražavanje poznatim idiomom radi uspješnijeg daljnjeg razvoja komunikacijske kompetencije i, u ovom dokumentu također istaknutog, suzbijanja straha od jezičnog izražavanja u školi (MZO 2019). Na kraju 2. razreda učenici bi trebali moći uspoređivati mjesni govor i hrvatski standardni jezik, na kraju 3. razreda kreativno se izražavati dijalektom / mjesnim govorom te znati koristi li se zavičajni govor ili hrvatski standardni jezik u pojedinoj komunikacijskoj situaciji. U 4. razredu učenici uče o svim hrvatskim narječjima uz prepoznavanje važnosti učenja standardnoga jezika i pozitivnoga odnosa prema mjesnom govoru te se nadalje $u$ višim razredima usložnjava njihovo znanje o varijetetima hrvatskoga jezika i primjena toga znanja. Terminologija u dokumentu nije

3 Kao i drugdje u osvrtu na dokumente upotrebljavaju se nazivi iz pojedinoga dokumenta. U NOK-u piše hrvatski standardni (književni) jezik. 
ujednačena kako se može vidjeti i iz prethodnih redaka, no očigledno je da su se uvažile spoznaje o usvajanju jezika, potrebi pozitivnoga vrednovanja standardnoga i nestandardnoga varijeteta, pa i ostale spoznaje o korisnosti uporabe djetetova govora u učionicama od polaska u školu barem na razini diskursa jezične obrazovne politike.

Makar je očita promjena u diskursu vezanom uz jezičnu obrazovnu politiku de iure, nije dokraja jasno do koje se mjere i na koji način takav diskurs pretače u nastavni proces (jezičnu politiku de facto), a zatim odražava u jezičnim praksama učenika (npr. Turza-Bogdan 2011, Pavličević-Franić-Aladrović Slovaček 2017). Jezične prakse nastavnika i pristup nestandardnim varijetetima na nastavi, kao i usvojena znanja, vještine, stavovi i vrijednosti učenika dijelom otkrivaju kakve su zakonske odredbe na snazi te kako su ih nastavnici razumjeli i prihvatili te ćemo ih pomnije analizirati kasnije.

\section{Jezične specifičnosti govora Makarskog primorja}

Govori Makarskoga primorja nekada su pripadali makarskoprimorskome dijalektu, dijelu zapadne štokavštine (Brozović 1970). Danas su to novoštokavski govori (zapadnog bosanskohercegovačkog dijalekta) s četiri naglaska i zanaglasnom duljinom, ikavski i dijelom šćakavski govori (Kurtović Budja 2009, Šimičić i sur. 2013) na koje utječu, među ostalim, govornici susjednih dijalekata te došljaci iz drugih hrvatskih govornih područja. Uporaba stranih jezika, posebice engleskoga jezika kojemu su govornici sve više izloženi putem medija te u komunikaciji s turistima, posebno se osjeća u govoru mladih koji se u tom aspektu ne razlikuje mnogo od mladenačkog govora i drugdje u Hrvatskoj (usp. Skelin Horvat 2017) pa se u ovome dijelu nećemo posebno osvrtati na njega.

Prema Kurtović Budja (2009), koja je detaljno istražila ove govore, donosimo pregled osnovnih obilježja. Dok nisu česte redukcije samoglasnika, u svim se govorima zamjećuje pojednostavljivanje suglasničkih skupova. U većini je govora ukinuta razlika između dva para afrikata te suglasnički inventar čine tzv. srednje $\check{c}$ i $d$, osim u zaostroškom i gradačkom govoru. Ni u jednom govoru ne javlja se glas $h$, a za $f$ se nalaze potvrde samo u posuđenicama. Glas $l$ izgovara se umekšano. I adrijatizmi poput zamjene završnoga $m \mathrm{~s} n$ i promjene sonanta $l j \mathrm{u} j$ također su karakteristični za ove govore. Što se pak tiče završnoga $l \mathrm{u}$ glagolskome pridjevu radnom muškoga roda, od Brela do Makarske suglasnik - $l$ mijenja se u -(j)o (osim kada glagolska osnova završava samoglasnikom $a$, tada $l$ daje $a$ ), a od Tu- 
čepi ${ }^{4}$ do Graca suglasnik - $l$ na kraju riječi, odnosno u dočetnom slogu zamjenjuje se s-(j)a. U imenicama, pridjevima i prilozima ostvaruje se -al, -ol, $-u l,-i l$ (uz -ija), -el (uz -eja). Mogu se čuti oblici s rotacizmom: npr. moreš, more, mere, moremo, morete. Kod glagola 2. vrste infinitivi imaju -ni-, a infinitivi su općenito apokopirani ili nemaju nastavak -ti: vikni. U prezentu se u 3. 1. mn. javlja nastavak - $u(t u c ̌ u, v i d u)$. Aorist se čuva u 3. 1. jd. kao što se čuva i imperfekt glagola biti (Kurtović Budja 2009). U D i L jd. ž. r. pridjevsko-zamjeničke deklinacije nalazi se nastavak -on (mojon sestri) kao posebnost govora ovoga područja koja se uočava kod govornika svih uzrasta (Kurtović Budja 2009:116-117; usp. i Lisac 2003, Hraste 1951, Halilović 1996). O govoru mladih u Makarskom primorju Kurtović Budja zaključuje da je sličan govoru mladih iz ostalih štokavskih dalmatinskih predjela, pri čemu su njegove specifičnosti: šćakavizam, za koji mi u svom istraživanju ne nalazimo mnogo potvrda, umekšano izgovoreno $l$, duljenja pred sonantima te očuvanost zanaglasne duljine (Kurtović Budja 2009:168-169).

\section{Metodološki okvir istraživanja}

Analiza jezičnih praksi osnovnoškolaca temelji se na materijalu prikupljenom tijekom terenskog istraživanja provedenog 2018. i 2019. godine u Makarskome primorju. Dio podataka prikupljen je sociolingvističkim upitnikom, a dio dubinskim intervjuima s različitim dionicima u procesu upravljanja jezikom (nastavnicima, administrativnim osobljem škola, roditeljima), no u ovom radu analizu temeljimo isključivo na razgovorima s nastavnicima. U nastavku pobliže opisujemo uzorak i metodološke postupke u dvama navedenim dijelovima istraživanja.

\subsection{Provođenje sociolingvističkih upitnika}

Dio je podataka prikupljen sociolingvističkim upitnicima provedenima u osnovnim školama u mjestima Makarska, Brela, Tučepi, Podgora, Gradac i Drvenik. Iako je upitnik, zbog obujma i zahtjevnosti, bio namijenjen prvenstveno učenicima sedmih i osmih razreda osnovnih škola, njime je obuhvaćen i dio učenika šestih i u manjoj mjeri petih razreda osnovnih škola u navedenim mjestima. Upitnikom su se prikupljali podaci o obilježjima ispitanika (dob, spol, mjesto rođenja i podrijetlo), njihovoj jezičnoj identifikaciji, jezičnim stavovima i uvjerenjima (Garrett i sur. 2003) kao i njihovoj percepciji višejezičnosti, odnosno prisutnosti različitih govora u Makarskome primorju, dok je u posljednjem dijelu upitnika pri-

\footnotetext{
4 Navodimo lokalni oblik G imenice Tučepi poštujući sklonidbu imena mjesta zastupljenu među stanovništvom Makarskoga primorja.
} 
mijenjena percepcijsko-dijalektološka metoda (Preston 1989, NiedzielskiPreston 2000), no analiza tog dijela upitnika ne prikazuje se u ovome radu. Središnji dio ovog sociolingvističkog upitnika čine tri grupe pitanja koja se odnose na jezične prakse ispitanika u različitim društvenim domenama. Fishman (1972) domene definira s obzirom na prisutne sudionike, mjesto na kojem se interakcija odvija kao i teme kojih se interakcija dotiče. Zbog ograničene prirode upitnika kao mjernog instrumenta, posebice kako bi se izbjegao zamor kod mlađih ispitanika, u osmišljavanju upitnika usmjerile smo se isključivo na pojednostavljeno razdvajanje domena s obzirom na lokaciju i to a) formalnu (škola) i b) neformalnu (izvan škole). Također, za potrebe ovog upitnika obje su domene definirane prvenstveno sugovornicima (članovi obitelji, prijatelji, susjedi, (određeni) nastavnici i sl.), ali ne i drugim kontekstualnim elementima (prostorom, djelatnošću, specifičnom školskom aktivnošću i dr.). Od ispitanika se tražilo da označe koriste li s navedenim sugovornicima »lokalni govor Makarskog primorja«, »hrvatski književni jezik«i/ili »neki drugi jezik; ako da, koji«; bili su pritom dozvoljeni i višestruki odgovori. Osim podataka o samoprocjeni uporabe određenih varijeteta $\mathrm{u}$ zadanim situacijama, analizu smo jezičnih praksi temeljile i na jezičnoj analizi pisanog uratka prema slikovnom predlošku. U navedenom su zadatku ispitanici dobili mogućnost opisivanja dvaju crteža u nekoliko rečenica s naputkom da se izraze onako kako bi ih opisali svojim prijateljima. Na crtežima su prikazane dvije neodređene životinje koje imaju opremu za sunčanje te jedu i piju na plaži, a uz njih se još nalaze pas, galebovi i cvrčak.

U ovom je dijelu istraživanja sudjelovalo ukupno 333 ispitanika (163 dječaka i 166 djevojčica te 4 neizjašnjenih). Od navedenih 191 učenik je iz Makarske (iz OŠ Stjepana Ivičevića i OŠ Petra Perice), 13 iz Brela (OŠ Brela), 40 iz Tučepi (OŠ Tučepi), 35 iz Podgore (OŠ don Mihovila Pavlinovića), 37 iz Graca (OŠ Gradac) i 17 iz Drvenika (PŠ Drvenik). Gotovo polovina ispitanika pohađala je osmi razred $u$ vrijeme istraživanja $(N=160)$, dvostruko manje sedmi $(\mathrm{N}=79)$ i šesti $(\mathrm{N}=76)$ razred te znatno manje peti razred $(\mathrm{N}=18)$. Po dobnim skupinama, oko trećine ispitanika $(28,5 \%$, $\mathrm{N}=95)$ ima do 12 godina, oko četvrtine $(25,2 \%, \mathrm{~N}=84)$ ima 13 godina te gotovo polovina ( $45 \%, \mathrm{~N}=150)$ ima između 13 i 15 godina; prosječna je dob ispitanika 13,13 godina. Što se porijekla tiče, otprilike polovini sudionika je barem jedan od roditelja iz Makarskog primorja (otac 182 sudionika, odnosno 54,66 \%, a majka 133 sudionika, odnosno 39,94\%), mnogo manjem broju njih iz drugih dijelova Dalmacije (otac 35 sudionika, ili 10,51 \%, a majka 46 sudionika ili 13,81 \%) ili ostalih dijelova Hrvatske (otac 30 sudionika ili 9,01\%, a majka 52 sudionika ili 15,62 \%). Dio sudionika navo- 
di da im je barem jedan od roditelja rođen izvan Hrvatske (uglavnom iz $\mathrm{BiH}$, ali ne samo odatle) i to otac 68 sudionika (20,42\%) i majka 84 sudionika $(25,23 \%)$.

\subsection{Kvalitativno istraživanje}

Kvalitativna analiza temelji se na iskazima sugovornika - dionika u odgojno-obrazovnom procesu u školama u kojima je provedeno i prikupljanje kvantitativnih podataka. Razgovori $\mathrm{u}$ formi polustrukturiranih intervjua provedeni su s ukupno petnaest sugovornika, no samo je dio intervjua, i to onih provedenih s nastavnicima, bio prikladan za analizu koja slijedi. Gordana $(S 1)^{5}$ je učiteljica razredne nastave koja je u djetinjstvu doselila u Makarsko primorje, ondje predaje već gotovo četiri desetljeća te tvrdi da dobro poznaje lokalni govor. Olga (S2) je učiteljica razredne nastave u osnovnoj školi u južnom Makarskom primorju, a aktivno vodi i izvannastavne aktivnosti kojima je jedan od glavnih ciljeva njegovanje lokalnog govora. Sanja (S3) također sebe smatra govornicom makarskog govora, u školi predaje Hrvatski jezik. Isti predmet predaje i Dijana (S4), govornica jednog lokalnog govora Donjeg, odnosno sjevernog Makarskog primorja. Marija (S5) je govornica štokavsko-ikavskog govora, profesorica je Hrvatskog jezika koja je u Makarsko primorje doselila tek po završetku studija. Marko (S6) je nastavnik u osnovnoj školi, a sam je govornik igarskog govora. Osim polustrukturiranih intervjua koji su trajali između 20 i 90 minuta, dio zapažanja proizlazi i iz neformalnih nesnimljenih razgovora s nastavnicima i osobljem škola u kojima su se provodila istraživanja (vidi 5.1.). Svi su sugovornici čije iskaze navodimo dali usmeni pristanak na snimanje intervjua u svrhu provođenja istraživanja.

\section{Analiza jezičnih praksi}

Jezične prakse osnovnoškolaca u ovom radu analiziramo na temelju a) podataka prikupljenih sociolingvističkim upitnikom koji dijelom uključuje i samoizvješćivanje osnovnoškolaca o vlastitom jezičnom ponašanju u određenim kontekstima i b) razgovora u kojima odrasli sugovornici i dionici jezičnog upravljanja u formalnom obrazovanju iznose vlastita zapažanja o jezičnim obilježjima i praksama mladih u Makarskome primorju.

5 Radi zaštite privatnih podataka u tekstu koristimo pseudonime. Oznake S1, S2 itd. koristimo isključivo za označavanje govornika u citiranju dijaloga između istraživačice (I) i sugovornika (S). 
6.1. Kvantitativna analiza jezičnih praksi u formalnim i neformalnim kontekstima

Većina ispitanika $(66,07 \%, \mathrm{~N}=220)$ navodi da im je lokalni govor prvi naučeni jezik, dok ih tek oko četvrtine navodi da im je prvi naučeni jezik hrvatski standardni varijetet $(25,23 \%, \mathrm{~N}=84)$, odnosno neki drugi jezik $(2,7 \%, \mathrm{~N}=9)$. Za ovo su pitanje Kruskal-Wallisovim testom potvrđene statistički značajne razlike $u$ odgovorima ispitanika $s$ obzirom na a) mjesto rođenja $\left(\chi^{2}=6,98, p=0,03\right)($ Slika 1$)$ te $\left.b\right)$ porijeklo oca $\left(\chi^{2}=16,87\right.$, $\mathrm{p}=0,001)$ i majke $\left(\chi^{2}=13,59, \mathrm{p}=0,004\right)$. Iako u grupi ispitanika rođenih u Makarskom primorju većina ispitanika navodi lokalni govor kao prvi naučeni jezik, pitanje da ga specificiraju kod većine je ispitanika izazvalo zbunjenost, a odgovori ukazuju na vrlo neujednačenu uporabu. Sudionici ovog dijela istraživanja tek iznimno imenuju lokalne varijetete (npr. makarski ili makaranski, grački, brđanski, dalmatinsko-igarski, podgorski ikavski ili »dalmatinski, štokavski, podgorski« kao nazive za lokalni govor), dok većina u ovom kontekstu spominje dalmatinski s varijantama npr. »lokalni dalmatinski govor «, »dalmatinski hrvatski«, »dalmatinski jezik«. Dio ispitanika kao naziv vlastitog govora navodi općenite nazive s obzirom na tip govora, npr. štokavski, ikavski ili ikavica, a nekolicina lokalni govor naziva »naški«.

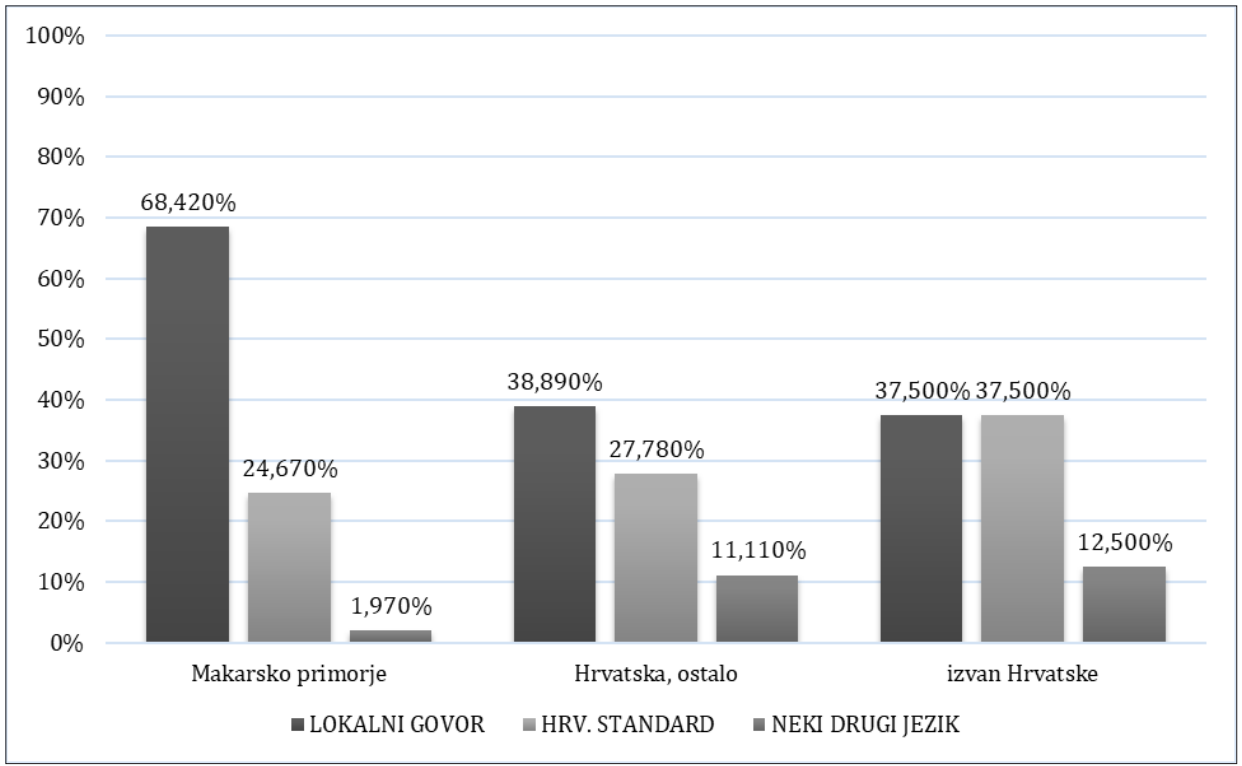

Slika 1. Prvi naučeni jezik s obzirom na mjesto rođenja ispitanika 
Lucija Šimičić, Marija Ćubelić: Između standardnog varijeteta i lokalnih govora...

FILOLOGIJA 76(2021), 201-251

Ne specificirajući domene jezične uporabe, više od dvije trećine ispitanika navodi da se uglavnom služi lokalnim govorom $(71,8 \%, \mathrm{~N}=239), 16 \%$ $(\mathrm{N}=54)$ standardnim varijetetom, a svega 5,1 \% ( $\mathrm{N}=17)$ nekim drugim jezikom. Navedeni drugi jezici najčešće se odnose na jezike (jednoga od) roditelja (npr. češki, slovački, albanski, bosanski ili bosansko-hercegovački), neki svjetski jezik koji uče u školi (engleski, njemački) ili, u manjem broju slučajeva, neki lokalni ili nadlokalni varijetet (dalmatinski, brački, drašnički). Ipak, Kruskal-Wallisovim testom potvrđena je statistički značajna razlika među govornicima različitog porijekla u samoizvješćivanju s obzirom na najčešće korišten jezik općenito $\left(\chi^{2}=9,6, p=0,008\right)$ pri čemu oni rođeni u Makarskom primorju najviše prijavljuju lokalni varijetet kao uobičajeni jezik $(74,01 \%, \mathrm{~N}=225)$, dok ih to čini 38,89\% $(\mathrm{N}=7)$ rođenih u drugim dijelovima zemlje i $50 \%(\mathrm{~N}=4)$ rođenih izvan Hrvatske (Slika 2).

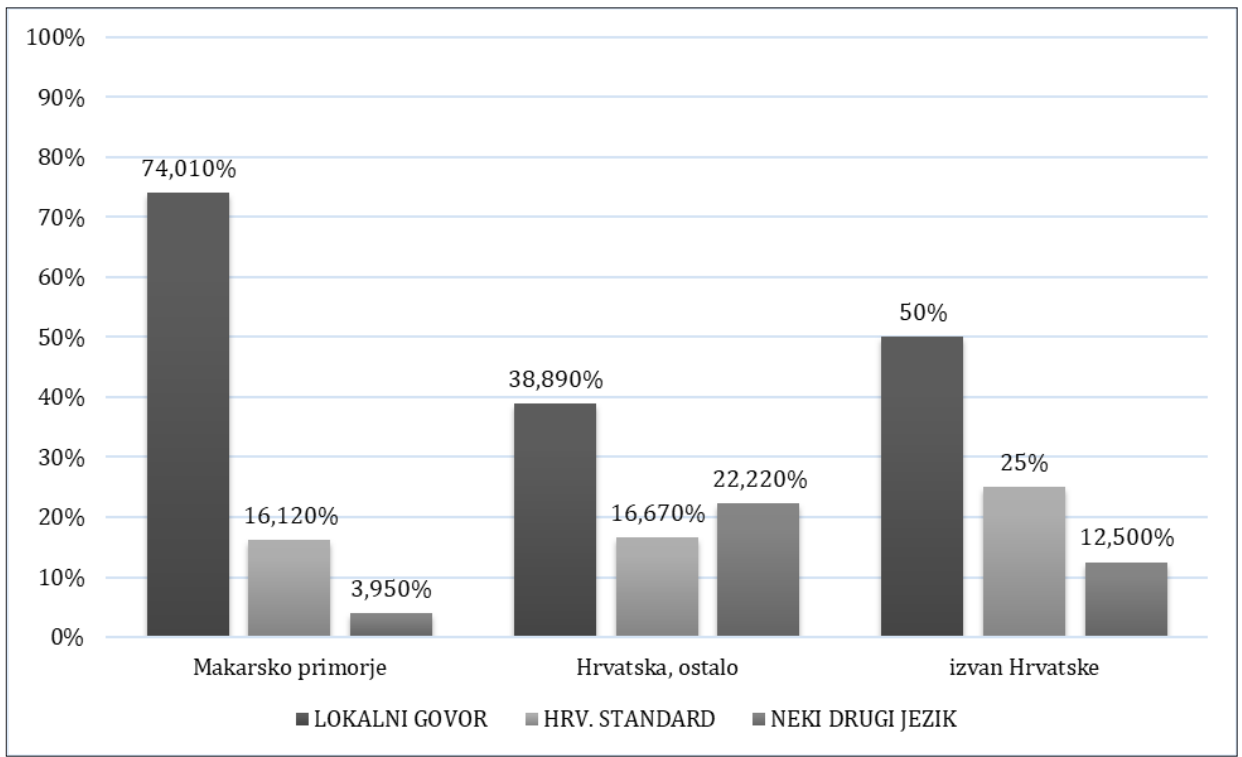

Slika 2. Najčešće korišten jezik s obzirom na mjesto rođenja ispitanika

Sličnu tendenciju pokazuju i odgovori na pitanja koja se odnose na najčešću uporabu jezika u neformalnim domenama. U takvim situacijama pretežno lokalni varijetet, makar ne nužno uvijek, odabire 78,85 \% sudionika istraživanja $(\mathrm{N}=261)$, mnogo manje standardni varijetet $(19,36 \%$, $\mathrm{N}=64)$ i najmanje neki drugi jezik $(1,81 \%, \mathrm{~N}=6)$. Pritom, najveći udio naših sudionika navodi da lokalni varijetet rabi u društvu prijatelja $(88,18 \%$, $\mathrm{N}=291)$, zatim u užoj obitelji s ocem $(87,46 \%, \mathrm{~N}=286)$, braćom i sestrama $(86,28 \%, \mathrm{~N}=264)$, s majkom $(85,46 \%, \mathrm{~N}=282)$ i tek zatim s bakama i 
djedovima $(84,47 \%, \mathrm{~N}=272)$. Lokalni varijetet očekivano najmanje rabe u razgovoru s djecom iz drugih dijelova zemlje koja ljetuju u Makarskom primorju $(59,52 \%, N=197)$ i sa župnikom $(56,09 \%, N=175)$. Nešto više od trećine označilo je korištenje isključivo lokalnog varijeteta $(35,7 \%, \mathrm{~N}=119)$, dok je nizak udio onih koji su naveli isključivu uporabu standardnog varijeteta $(3,6 \%, \mathrm{~N}=12)$, odnosno nekog drugog jezika $(0,9 \%, \mathrm{~N}=3)$; svi ostali govornici navode neku od kombinacija lokalnog i standardnog varijeteta ovisno o sugovorniku.

Nasuprot tomu, u školskom su kontekstu jezične prakse nešto raznovrsnije, no kao i u neformalnim domenama i u ovom slučaju ovise o sugovorniku. Ondje oko polovine sudionika u većini govornih situacija koristi neki od lokalnih varijeteta $(51,66 \%, \mathrm{~N}=171)$ i gotovo jednako toliko standardni varijetet $(48,04 \%, \mathrm{~N}=159)$, premda nisu rijetki ni oni koji rabe oba varijeteta, ovisno o situaciji u kojoj su se našli. I u ovom slučaju većina prilagođava jezičnu uporabu, ne samo domeni već posebno sugovorniku/-icima što rezultira prilagođavanjem jezične prakse specifičnim mikrokontekstima. Tako odabir govora s prijateljem u klupi ili na odmoru neće biti istovjetan onome na satu Hrvatskog jezika ili u razgovoru s nastavnicima čak i izvan učionice. Većina sudionika očekivano smatra da standardni varijetet koriste na nastavi i to naročito na satovima Hrvatskog jezika $(78,85 \%$, $\mathrm{N}=261)$ i znatno manje na satovima Matematike $(52,73 \%, \mathrm{~N}=174)$ ili izbornih predmeta. Više nego u posljednja dva slučaja, standardni varijetet rabe s nastavnicima izvan učionice $(61,99 \%, \mathrm{~N}=199)$ i s drugim stručnim osobljem u školi (npr. pedagogom, psihologom, ravnateljem) (68,20\%, $\mathrm{N}=223$ ); ipak, za ovu posljednju skupinu potencijalnih sugovornika nemamo podatak koliko je sudionika zaista s njima u kontaktu pa je moguće da dio odgovora odražava pretpostavljenu ili očekivanu jezičnu praksu s obzirom na naučenu normu. Za razliku od navedenih, odabiri jezičnih kodova u razgovoru s prijateljima tijekom odmora uglavnom su podudarni odabiru jezika i u ostalim neformalnim domenama $(89,43 \%, \mathrm{~N}=296$ ih odabire lokalni varijetet), dok u razredu dio ispitanika čak i u razgovoru s prijateljem iz klupe prema navodima rabi standardni varijetet $(13,29 \%$, $\mathrm{N}=44$ ). Prema Kruskal-Wallisovom testu razlika među govornicima s obzirom na mjesto rođenja statistički je značajna kako u neformalnim domenama $\left(\chi^{2}=8,77, \mathrm{p}=0,013\right)$ tako i u kontekstu škole $\left(\chi^{2}=6,35, \mathrm{p}=0,042\right)$ te, neovisno o domeni, sudionici rođeni u Makarskom primorju (u neformalnim domenama) ili oni rođeni izvan RH (u školskom okruženju) skloniji su rabiti lokalni varijetet, dok oni rođeni u drugim dijelovima Hrvatske znatno češće navode korištenje standardnog varijeteta neovisno o funkcionalnoj domeni. 
Primjenom Kruskal-Wallisovog testa za testiranje razlika među različitim grupama ispitanika s obzirom na porijeklo oca, odnosno majke, pokazalo se da među ispitanicima postoji statistički značajna razlika u odgovorima o jeziku koji najčešće rabe $\left(\chi^{2}=12,02, p=0,01\right.$ kada se radi o porijeklu oca, odnosno $\chi^{2}=12,19, p=0,01$ kada je u pitanju porijeklo majke) kao i u grupi pitanja koja se odnose na najčešće korišten jezični varijetet $\mathrm{s}$ različitim sugovornicima $u$ neformalnim domenama $\left(\chi^{2}=17,95, p=0,001 \mathrm{~s}\right.$ obzirom na porijeklo oca, odnosno $\chi^{2}=17,74, \mathrm{p}=0,001 \mathrm{~s}$ obzirom na porijeklo majke). Kada je riječ o najčešće upotrebljavanom jezičnom kodu u školskom kontekstu kao primjeru formalne domene, rezultati upućuju na to da je porijeklo samo oca, ali ne i majke, u tom kontekstu relevantno $\left(\chi^{2}=9,58, \mathrm{p}=0,02\right)$.

Testiranjem korelacija Pearsonovim korelacijskim testom utvrdile smo značajnu pozitivnu korelaciju između prvog jezika kao i jezične identifikacije koje mogu biti podudarne, no ne uvijek, i uporabe određenog jezika ili varijeteta u gotovo svim istraživanim domenama. Statistički značajna korelacija izostaje jedino u kontekstu odabira koda u komunikaciji s nastavnicima Hrvatskog jezika ( $\mathrm{p}<0,05)$. Mjesto rođenja ispitanika nije se pokazalo relevantnom kategorijom $(p<0,05) \mathrm{s}$ obzirom na jezičnu uporabu $u$ većini ispitivanih situacija.

\subsection{Analiza opisa slike}

Ispitanicima je dana mogućnost da svoje poznavanje lokalnog govora i pokažu u opisivanju dviju slika u slobodnoj formi. U tom su zadatku imali prilike pokazati do koje mjere vladaju lokalnim govorom te su tu jezičnu kompetenciju tek djelomično pokazali iz više razloga: a) zbog navike i zahtjeva da veliku većinu pisanih sastava pišu na standardnom varijetetu, b) zbog percipirane dekontekstualiziranosti zadatka (tražilo se od njih da pisanim medijem opišu sliku kao da je opisuju svojim prijateljima) i, konačno, c) zbog slabog poznavanja specifičnog rječnika lokalnog govora kojim bi opisali pojedinosti na slici.

Ikavštinu, temeljno obilježje koje se zapaža i u govoru učenika ispitanika, uočile smo u mnogim riječima (dili, lipo, dite, side, odnila, lito, sritan, prislanu, čovik), no primjetno je mnogo standardnojezičnih oblika i uporabe ijekavice (negdje u skladu sa standardom, negdje ne) $\mathrm{u}$ primjerima $\mathrm{u}$ kojima se mogao očekivati ikavski refleks jata (sjede, podijelili su, u pjesku uz pijesak i uz jedno na pisku, djete uz dijete). Glagol jesti u različitim glagolskim oblicima učenici pišu onako kako se upotrebljava u standardu (jede, jedu, pojede, pojeo je, pojesti), ali i onako kako se može čuti u lokalnim govorima Makarskoga primorja (idu, jide, izili, jea, jio je, poija je, ija je, ia je, pojist). Je- 
Lucija Šimičić, Marija Ćubelić: Između standardnog varijeteta i lokalnih govora...

dan je ispitanik napisao $i d u$ (za 3. 1. mn.), no u zagradi je naveo i oblik jedu kao objašnjenje, dok je jedan drugi ispitanik napisao jedu pa u zagradama naveo i oblik $i d u$. Dočetno $-m$ ispitanici su ponekad zamjenjivali s $-n$ : $n e-$ man, s hrenovkon, s drugon, s materon, vidin, prolazin, sa svojon babon, sa većin hrčkon, bilo in je, sa njon uz oblike sa svojom materom, s svojom mamom, vidim, nemam, dok je jedan ispitanik napisao sa svojom materon. Uz ikavštinu i prijelaz $-m \mathrm{u}-n$ govore Makarskoga primorja obilježava delateralizacija $(l j>j)$ koja se tek u opisima četvero ispitanika uočava u riječima oduševjena, ležajku, ležajci. Šćakavizam je karakterističan za govore Makarskoga primorja, dijalektolozi su ga uočavali i kod svojih mladih ispitanika (usp. Kurtović Budja 2009), a mi tek kod jednoga ispitanika imamo oblike poput (neki) ščakor, (dva) šćakora. U odgovorima ispitanika nalazimo zamjenicu šta (ponegdje što uz štagod, štogo, pa i jedan nešta).

Ima ispitanika koji ne pišu u skladu s pravopisnim pravilima riječi s glasovima č i ć: on moći (od močiti), ježič, povrče, sendvić (uz sendvič), čuko (uz ćuko), što je dijelom i očekivano s obzirom na a) prirodu zadatka, tj. zahtjev da se u opisu slike služe varijetetom koji rabe u neformalnim situacijama i b) činjenicu da se na makarskom području afrikate neutraliziraju zbog čega, među ostalim, neki ne razlikuju č i ć u pismu.

Glas $h$ javlja se u jezičnom sustavu učenika u riječima stranoga podrijetla (hrenovka uz hot-dog / hot dog / hotdog / Hot Dog / Hot-Dog / hot dogove i sl., ali je zabilježeno i muha) pri čemu ispada ili se zamjenjuje $\mathrm{s} v \mathrm{u}$ riječima kao što su rana (dosta ispitanika pisalo i hrana), vataju, ladno (piće), skuva, dok kruv nalazimo u velikom broju uz oblik kruh. Glas $f$ nalazimo u riječima poput kifla, fotografija.

Ispitaniku (u ovom dijelu rada ne navodimo je li riječ o učeniku ili učenici) čiji je otac podrijetlom sa sjevera Hrvatske u opisu nalazimo oblik karakterističan za sjeverne varijetete: $k a k(<k a k o)$. Roditelji učenikâ uglavnom su iz Makarskoga primorja, Dalmatinske zagore i Bosne i Hercegovine, tj. Hercegovine, no ima ih i iz drugih dijelova Hrvatske, kao i iz inozemstva. Govori roditeljâ utječu na govor djece i kada se razlikuju od govora sredine u kojoj obitelj živi. Drugi ispitanik koji je prema očevu podrijetlu također povezan sa sjevernim krajevima Hrvatske koristi ikavštinu u svom opisu slike (dva zeca side), ali glagol jesti u 3. 1. mn. prezenta spreže kao (oni) jedu.

$\mathrm{U}$ opisima osnovnoškolci rabe oblike glagolskoga pridjeva radnog $\mathrm{u}$ kojima se ostvaruje -(j)o ili -(j)a na mjestu završnoga -l, s tim da u školama od Makarske do Graca nailazimo na obje inačice: dao je, stavio je, prolio je, došao je, uzeo je, ošao/otišao je, napravio je, odnio je, izio je, da je, stavija je, doša 
je, otiša je, prolialprolija, umočia je, donija je, bia/bija je, uzea je, nije svidia, pojia bi, pra je, vratia ga, prerušia se, toča je... Utjecaj standardnoga jezika opaža se primjerice u: pojeo/pojela je, podijelio je, krenuo je, nije htjela, pa i odnjeo. Ispitanik čiji je otac iz Dalmacije, a majka iz Hercegovine rabi oblik odnjeo je, opro je te je u opisu naveo štakor, do svoje majke, sjeli su, jeli su u čemu primjećujemo težnju k standardu i obilježja ispitanikova idiolekta koja nisu karakteristična za Makarsko primorje.

Ispitanici ne skraćuju uvijek infinitive, a ima i apokopiranih infinitiva: kupati, podijeliti, jesti, igrati, hraniti, kupat, ist (jesti, op. autorica), pojest, ponašat, oprat, posolit, uć... Kod dvaju ispitanika otpada -ti u infinitivu, npr.: izis, da, bi će, okupa, bi'će.

Od drugih obilježja značajnih za glagolske oblike u govorima u Makarskome primorju treba istaknuti oblik zovnila koji je napisao jedan ispitanik, drugi ispitanik napisao je $i đ e$, a nalazimo i nekoliko primjera karakterističnoga 3. 1. mn. prezenta s nastavkom -u: Ptice letu.; (Oni) ležu.

Zamjenicu njoj nalazimo na jednom mjestu u lokalnom obliku jon: ...i da jon hrenovku da izide. Nema drugih riječi u D i L jd. ž. r. s karakterističnim nastavkom -on, već ispitanici pišu: na prooj slici, na drugoj slici, na ovoj livoj slici, u lijevoj ruci, (da ga je) svojoj mami. Uočavamo u opisima dugu množinu (galebovi) te tek u jednom opisu kratku množinu (galebi) (usp. Kurtović Budja 2009).

Među onima koji su na slici vidjeli pse manji broj njih napisao je da je to ćuko/čuko, jedan ispitanik (prema podrijetlu roditelja iz Makarskog primorja) napisao je đukela, a većina je koristila riječ pas, pri čemu neki ispitanici oblike s umetnutim -a-: Vidin pasa., Pasi jedu kobasice., uz npr. Zeko sa psom baca kamenje., Imaju psa. Likove na slikama ispitanici su doživljavali na različite načine, pisali su da se radi o: dabru, hrčku, krtici, vjeverici, zamorcu, zecu, dikobrazu, psu, ježu, mišu, štakoru, pantagani, vidri, beštiji, živini, dječaku, momku, liku, dečku... Uočljivo je da se učenici osnovne škole koje smo anketirale služe leksikom karakterističnim za Dalmaciju, no upotrebljavaju i riječi karakteristične za standardni jezik. Osim u definiranju likova sa slike to, primjerice, vidimo kada u opisima nalazimo talijanizam šporko, ali i oblik uprljao je, a ne išporkao je. Anglizmi i engleski iskazi sve više postaju dio govora djece i mladih te u opisima nalazimo: hotdog (ispitanici su ovu riječ pisali različito), but he ain't about that life. Hotdog je u opisima i kobasica, hrenovka, kobasa, vruči/vrući pas. Ženski lik ispitanici su prepoznavali kao 'mamu' (mater, mama, mati, majka) ili 'baku' (baka, baba, na jednom mjestu nona). Jedan je ispitanik kraj riječi mater napisao u zagradi mama za objašnjenje. Ručnik je kod pojedinih ispitanika šugaman, šugoman, peškir. Uz na- 
očale nalazimo još očaleloćale, cvike. Suncobran su prepoznali i pisali su suncobran, premda je nekima to bio kišobran, lumbrela. Prilog poslije javlja se i u oblicima poslin, posli.

Kao neki ispitanici pišu ko/ka, a kao da spajaju u koda. Stapanje samoglasnika, pojednostavljivanje suglasničkih skupova i spajanja riječi nalazimo u mnogim govorima, međutim i u specifičnom jeziku djece i mladih, posebno pri komuniciranju pomoću tehnologije. Jezik interneta kojim se učenici svakodnevno služe kombinacija je govornoga i pisanoga jezika (Crystal 2001). Od učenika smo tražile da nam u pisanoj formi napišu što bi o slikama rekli te smo očekivale da ćemo moći prepoznati neke obrasce komuniciranja putem poruka i društvenih mreža u učeničkim odgovorima. Pisali su: koi, nie, nači/naći (umjesto znači), ode (ovde), glea (gleda) štae, dae, msm (mislim). Kako bi stvorili kontekst razgovora usmenim putem, bilo je ispitanika koji su započeli opisivanje obraćanjem pa tako možemo naići na: nu; vidi; na slici ti je; slušaj/slušoj, brate (takvih zatvaranja vokala nema u Makarskom primorju, a kod tog je ispitanika uočeno samo u toj riječi). Za početak su se neki poslužili riječima objašnjavanja: rećemo; e pa; nači/naći; znači.

Kod pojedinih ispitanika uočava se kombinirana uporaba i lokalnoga i standardnoga varijeteta kao što se moglo opaziti u prije istaknutoj sintagmi sa svojom materon, a što se događa i na razini rečenice i opisa. Neki ispitanici pokazali su, pak, obilježja lokalnih varijeteta krajeva izvan Makarskoga primorja s kojima su povezani njihovi roditelji.

\subsection{Percepcija jezičnih praksi osnovnoškolaca}

Podaci o jezičnim odabirima i praksama temeljeni su dijelom na stvarnoj uporabi (u opisu slike, što je prikazano u 6. 2.), no više na samoizvješćivanju koje je često subjektivno i tek djelomično odražava stvarnu jezičnu uporabu, a istovremeno upućuje na jezični prestiž koji ispitanici pridaju nekom varijetetu u određenom društvenom kontekstu (Bayley-Lucas 2007:177). Tako je moguće da su djeca bila sklonija odgovarati da u školskom kontekstu koriste standardni varijetet jer znaju da to od njih većina učitelja traži ili da s bakama i djedovima koriste lokalni govor jer znaju da ga rabe njihovi sugovornici. Isto je tako moguće da jezik korišten $u$ opisu slika (v. 6. 2.) sadrži više standardnojezičnih obilježja, unatoč zadatku i uputama istraživača, pa ni on nije do kraja pouzdan $u$ analizi jezičnih praksi osnovnoškolaca Makarskog primorja. Upravo smo zato o jeziku mladih razgovarali s odraslima - učiteljima, nastavnicima Hrvatskog jezika i drugih predmeta, administrativnim osobljem škola, roditeljima - 
koji su svi promatrači jezičnog ponašanja mladih, ali ujedno i manje ili više utjecajni "menadžeri" jezika mladih o kojima skrbe u odgojno-obrazovnom procesu. $U$ razgovorima nas je zanimala njihova percepcija jezične osviještenosti mladih o posebnostima govora Makarskog primorja kao i njihova percepcija uporabe lokalnih varijeteta u različitim domenama.

Većina je naših sugovornika istaknula da mladi posjeduju svijest, prije o svom regionalnom govoru, negoli specifičnim lokalnim govorima, te da ga nazivaju dalmatinskim.

Tako da ono ka' ih ja pitan oni kažu da govore dalmatinski, oni sve to stave pod dalmatinski, ikavski govor [...] a ovo je, mi smo u biti novoštokavci ikavci, baš zapadnohercegovački ikavski [...] zato što mi te jezike dijelimo na standardni književni, to je onaj koji se uči i na lokalni, odnosno razgovorni, kako ti razgovaraš, ali ne znaju kako se taj jezik zove. (Dijana)

Dijana ističe mogućnost da je jezična osviještenost naglašenija na satovima Hrvatskog jezika u pogledu razlikovanja razgovornog i standardnog varijeteta negoli u drugim situacijama upravo zbog nespecifičnosti lokalnih govora u odnosu na dalmatinski regiolekatski koine. Čak i kada se $\mathrm{u}$ neformalnim razgovorima pojedini sugovornici referiraju na specifične lokalne idiome Makarskog primorja ističući njihovu međusobnu različitost, malo tko uspijeva navesti više od dva do tri specifična obilježja koja ih međusobno razlikuju. Mladi pak pokazuju veću sklonost ka geografski vrlo široko definiranom glotonimu koji ipak nitko ne poistovjećuje sa splitskim, odnosno dubrovačkim, urbanolektima. Jedino jezično obilježje koje svi sugovornici ističu kao tipično je ikavica, a njega i djeca smatraju najznačajnijom, ako ne i jedinom, posebnošću svoga govora koju i visoko vrednuju.

Ja sam sad neki dan - oni između sebe oni, oni dosta govore ikavicu to je ajde po meni minimum tog nekog našeg, naše posebnosti u govoru. Ikavica im je baš ono baš urođena. Al sad baš ti neki izrazi, ono braćolet, ti neki baš arhaični, mislim arhaični, zastarjeli naši izrazi, nisu baš njima toliko vrlo poznati. (Sanja)

Ikavicu čuvam, a ostalo gubim. (Marko)

I: Da i meni se čini da ikavica ima neki prestiž.

S5: Je, je to im je čak i nekako drago, čak ja i osjetim malo neku pobunu onako malo kad ih hoću ispraviti pa kao, to im je to bilo, mliko i dite i nekako su ponosni zbog tih riječi, znate (smijeh). (Marija)

Ako je dalmatinski govor osnovnoškolaca Makarskog primorja obilježen prvenstveno ikavicom uz koju dio mladih čuva i određene adrijatizme kao što su dočetno $-n$ (npr. u 1. l. sg. prez.) i delateralizacija $l j>j$ (npr. judi, divji...), naši sugovornici ističu da se od specifičnih morfoloških obi- 
Lucija Šimičić, Marija Ćubelić: Između standardnog varijeteta i lokalnih govora... FILOLOGIJA 76(2021), 201-251

lježja kod djece porijeklom iz Makarske i Primorja još uvijek čuva i dočetno $-u$ u 3. l. mn. prezenta glagola:

Radu, radu (smijeh), to ste isto vjerojatno primijetili... Radu, idu, neki to i kažu to je već pod utjecajem starijih, ako se u kući jezično oblikuje njihov govor. (Marija)

Ostale fonološke i morfološke specifičnosti naši sugovornici smatraju lokalizmima, arhaičnim i/ili ruralnim jezičnim obilježjima prisutnima u govoru još samo starijih govornika.

S1: Recimo latak je čisti lokalizam.

I: A vi imate djecu koja tako govore?

S1: Ne. Nema zato što vam se u Makarskoj ne govori latak. Znate gdje vam je to? Tučepi. To vam je Tučepi latak, Tučepi, Podgora ovaj dio. Latak, lataaaj. U Makarskoj se dosta to izgubilo. (Gordana)

Ovaj gušćer, šćap? A to djecu nisam čula, to je kod starijih ljudi, onako baš u kasnim godinama života. Gušćerica ja to često ne čujem, u školi ne. (Marija) S3: Po mome mišljenju najkarakterističnije je [...] to da prezent ne završava sa $m$ nego sa $n$. To redovno i u pisanom obliku izražavanja, radin a ne radim, pišen domaći to aaa...ono $h$ pa $v$ nije ovaj...[...] Frane u Vrane, ee a to stari I: To znači stari, to mladi više. [...] A vi?

S3: Mmm ne. Ja sam tako čula zato i znam da je to tako, ali nisam to nikad upotrijebila. (Sanja)

S5: A kod starijih sam ljudi čula sam riječi kliko, šešnajst, to je meni ovako bilo čudno to sam prvi put čula ovdje, latak, kliko, šešnajst.

I: A čuju li se kod mlađih?

S5: E kod mlađih ne. Kod mlađih ljudi otkad sam ja u školi to stvarno nisam čula. (Marija)

Ako su mladi iz svog govora eliminirali niz specifičnih fonetskih i morfoloških obilježja kao i velik dio leksika, posebice onoga romanskoga porijekla, kod dijela govornika mlađe generacije porijeklom iz Makarskog primorja neka su od tih obilježja i dalje latentno prisutna u njihovim jezičnim repertoarima. Ona obilježja koja su očuvana još jedino u govoru starijih i/ili ruralnih govornika, dok su iz jezičnih repertoara mlađe pa čak i srednje generacije nestala, kao što su npr. šćakavizam, metateze, asimilacije suglasnika na daljinu, disimilacije suglasnika itd., nerijetko su i stigmatizirana te se poistovjećuju s niskom razinom obrazovanja čak i među lokalnim govornicima.

I: Čak i mlađi to govore?

S1: Pa iz neukosti svoje, da neki. Oni koji su učeni, neće, ali nažalost ima dosta neobrazovanih pa onda da, bez pardona. (Gordana) 
Ista sugovornica spominje i stilski motiviranu povremenu uporabu sad već uglavnom istisnutih obilježja lokalnih govora. Naime, oni mlađi govornici u čijim su jezičnim repertoarima takva obilježja prisutna makar na pasivnoj razini, eventualno ih koriste $\mathrm{u}$ određenim kontekstima u svrhu referiranja na specifične lokalne identitete ili u šali.

I: A dajte recite mi, rekli ste da su tu još ostali ti stari šešnajst i ne znam neki drugi...

S1: ...čigovo...

I: A je li to i mladi tako govore ili?

S1: Mladi vam danas iz zafrkancije tako govore, nema to više to su oni stari [...] (Gordana)

Svi su naši sugovornici u potpunosti svjesni jezičnih promjena koje su zahvatile govore Makarskog primorja i vidljive su u razlikama u govoru pojedinih generacija.

S4: Čuva se ikavica, ono $n$ na kraju, znači ono volin, ubacivanje $j$ ono bijo, volijo....ima ovdje dosta Hercegovaca, dosta Bosanaca, onda se to sve miješa, neće on reć bija, on će reć bio, sve se izmiješalo, poslije rata je ostalo dosta Bošnj-, Bosanaca, ovdje su se poženili, i sad od tih mojih učenika koji su došli nakon rata kao izbjeglice, kao djeca, ja sam njima predavala, a sad predajem njihovoj djeci.

I: Onda vi kroz ovih 25 godina vidite kako se mijenja taj jezik?

S4: Da, da, i sve manje je ovog našeg pravog, stvarno je izumrlo, sve manje... (Dijana)

Je, je, primjećujem da mlađi sve slabije poznaju mjesni govor i to. Kad sam tek počela raditi više su djeca koristila lokalizme. Sad mi se čini da je rijetko [...] (Marija)

Štoviše, više sugovornika ističe da učenici nailaze na probleme kada se od njih traži da se u pisanom obliku izraze na lokalnom govoru. Ne samo da ga tek rijetki poznaju već mnogima nedostaje adekvatna jezična podrška kod kuće koja bi im omogućila proširivanje znanja u lokalnim govorima, dakle roditelji, bake i djedovi kod kojih bi provjerili ili nadopunili svoje poznavanje lokalnog govora o čemu više govorimo kasnije (v. 7. 2.).

Svi naši sugovornici, bilo da su sami iz Makarskog primorja ili ondje već dulje žive, primjećuju jezične promjene u kojima rasprostranjenija jezična obilježja, koja mogu i ne moraju biti dijelom standardnoga varijeteta, istiskuju specifičnija, lokalna ili ona manjega dosega (usp. Šimičić 2011, Škevin Rajko-Šimičić 2019). Iako leksička razina nije uvijek najizloženija jezičnim promjenama, promjene u leksiku često su najzamjetnije te se nerijetko upravo one poistovjećuju s "izumiranjem" jezika. 
Lucija Šimičić, Marija Ćubelić: Između standardnog varijeteta i lokalnih govora...

FILOLOGIJA 76(2021), 201-251

I u to vrijeme kad sam ja išla u osnovnu školu govor je bio totalno drugačiji. Bile su stare domaće domicilne obitelji koje su potencirale domaći govor, znači ikavicu i normalno da tu ima puno talijanizama i svega i to se smatralo domaće. (Gordana)

I: Kako se i u kojim segmentima jezik mijenja?

S2: Jednostavno nestaju skupine riječi. Moja baba je govorila kotul za suknju i govorila je šugaman, moja mama i dalje govori šugaman, ali ne kotul, ja govorim šugaman, a moje dijete više ne govori ni šugaman. Dakle, sve manje i manje. I onda su se tu nama zbog turizma umiješale i riječi koje turisti koriste, ne znam Bosanci pa kažu peškir [...] (Olga)

Kao jedan od glavnih uzroka jezične promjene svi naši sugovornici navode doseljavanje štokavaca iz Zabiokovlja i posebno iz Bosne i Hercegovine. Migracije se nerijetko smatraju glavnim čimbenikom rastakanja lokalnog govora (usp. Šimičić-Bilić Meštrić 2018, Vuletić-Šimičić 2018), s jedne strane, i "miješanja" jezika, s druge. U diskursima naših sugovornika obje su pojave negativno obilježene, a odgovornost za njih prenosi se izvan lokalne zajednice.

[...] negdje tamo nakon rata, $\mathrm{u}$ ratu tih je migracija bilo, ili izbjeglice ili žene koje su se udale u Makarsku, i grad se širio, pravile su se zgrade, dosta ljudi sa strane je došlo tu živjet. E, kako su došli ljudi sa strane tako se i govor naše djece makarske mijenjao pod utjecajem vršnjaka znači oni koji su pričali ikavicom vršnjaci pričaju svojim zavičajnim govorom odakle su došli i djeca su fluidna i prihvaćaju sve to sa strane što dolazi. (Gordana)

S5: [...] Na makarskom govoru ja mislim da to možemo jedino kod starijih ljudi.

I: A zašto mislite da je tako? Što je uzrok tome?

S5: Pa vjerojatno je uzrok način života. Oni su vam puno dakle, internet sve odvikava, ovaj, doma se i ne priča baš na starom makarskom govoru

I: Čak ni oni koji jesu odavde?

S5: Pa ja vam čak to malo, dosta ima roditelja koji su, šta ja znam, rođenjem su negdje ili su iz Bosne došli, ili negdje iza Biokova, sve je nekako izmiješano. [...] Mi bismo rekli ima svega i svačega. Dakle ima tu i makarskih riječi, ima i riječi sa Biokova, ima nešto sa otoka, svega i svačega. [...] u osmom razredu, jedna učenica [...] ona lijepo napiše na lokalnom govoru, a ostala djeca, ta neka, neki čudni jezik, sve izmiješaju, pomiješaju. Ja i ne znam što je to ustvari. Tu vam ima i čakavizama, štokavizama, svega i svačega, znate. (Marija)

Dva navedena citata sadrže i u svim ostalim razgovorima prisutan diskurs o nestajanju "čistih" i "izvornih" makarskih govora te o njihovom zamjenjivanju "jezičnom mješavinom" kao posljedicom došljaka koji su, za 
razliku od domaćih, tvrdokorniji u zadržavaju vlastitih jezičnih obilježja te koja, barem djelomično, uspijevaju nametnuti djeci lokalnog porijekla. Diskurs o "miješanju" kao praksi koja narušava monolitno poimanje jezika jedna je od duboko usađenih jezičnih ideologija, snažno prisutna i u mnogim manjinskim kontekstima (usp. Schmidt 1985, Hill-Hill 1986, Jaffe 2007, Šimičić-Bilić Meštrić 2018 itd.) gdje je nerijetko okidačem jezične (auto-)stigmatizacije samih govornika, a preferiranje naizgled "čišćeg" (neovisno, dakako, o udjelu posuđenica, na primjer) i stoga "ispravnijeg" koda jednim od čimbenika njegova nestajanja iz jezičnog repertoara pojedinaca i zajednice u cjelini.

Drugi aspekt ovdje prisutnog diskursa implicira manjak djelatne uloge (eng. agency) lokalnih govornika koje je »stid pričat čistom ikavicom « za razliku od došljaka koji »svi njeguju svoju tradiciju [...] desetljećima žive tu svi vam pričaju kako su pričali prije nego što su došli, a naši se prilagođavaju«, a rezultat je da »tako negdje ovaj naš stari govor izumire« (Gordana). Iako je doseljavanje u Makarsko primorje u posljednjih dvadesetak godina bilo zamjetno (Mišetić-Bara 2011:25), diskurzno isticanje uloge jezično neprilagođenih doseljenika za jezično stanje zamagljuje mogućnosti djelatne uloge pojedinaca i lokalnih društvenih institucija (škole, obitelji i dr.) o čemu pišemo u kontekstu upravljanja jezikom u sljedećem dijelu rada.

\section{Analiza jezičnih stavova, jezičnih ideologija i upravljanja jezikom}

Do podataka za ovaj dio analize došle smo u manjoj mjeri analizom stavova učenika putem sociolingvističkih upitnika, a većinom na temelju iskaza sugovornika tijekom dubinskih intervjua ili kraćih i ne uvijek snimanih razgovora provedenih u osnovnim školama Makarskoga primorja tijekom terenskog rada.

7.1. Jezična identifikacija i jezični stavovi osnovnoškolaca u Makarskom primorju

U prvom se dijelu sociolingvističkog upitnika jedno od uvodnih pitanja, osim na identifikaciju prvog jezika kao i najčešće korištenog jezika, što smo obradile u prethodnom dijelu rada (6.1.), odnosi i na identifikaciju s određenim jezikom, odnosno jezičnim varijetetom. U odgovorima na to pitanje pokazalo se da se većina ispitanika $(69,07 \%, \mathrm{~N}=230) \mathrm{s}$ lokalnim govorom identificira, odnosno osjeća ga "svojim", dok ih to isto tvrdi za hrvatski standardni varijetet svega $18,92 \%(\mathrm{~N}=63)$, a 5,11 \% ( $\mathrm{N}=$ 
17) za neki drugi jezik; no, na to pitanje čak 23 ispitanika nije dalo odgovor. Daljnja analiza na temelju Kruskal-Wallisovog $\mathrm{H}$ testa pokazuje da su za jezičnu identifikaciju statistički relevantni mjesto rođenja $\left(\chi^{2}=18,83\right.$, $\mathrm{p}<0,001)$ (slika 3), ali i porijeklo roditelja, kako oca $\left(\chi^{2}=10,67, \mathrm{p}=0,014\right)$ tako i majke $\left(\chi^{2}=9,79, \mathrm{p}=0,021\right)$.

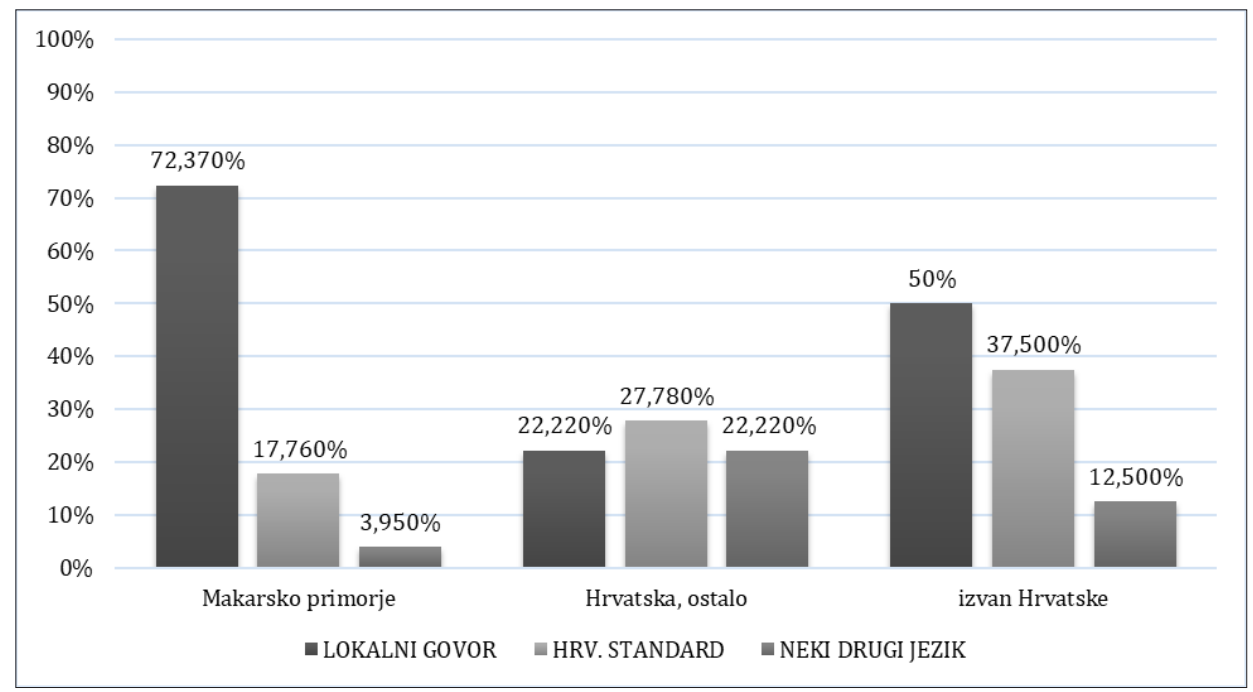

Slika 3. Jezična identifikacija osnovnoškolaca Makarskog primorja s obzirom na mjesto rođenja

Deskriptivna analiza ukupnog uzorka ukazuje na općenito visoko vrednovanje vlastitog govora koje svejedno nije u konfliktu sa samoprocijenjenim poznavanjem standardnog varijeteta $(\mathrm{M}=2,90, \mathrm{sd}=0,79)$. Mladi su mahom ponosni na vlastiti govor, koji god on bio $(M=3,32, s d=0,85)$ te njime uglavnom radije razgovaraju o osobnim temama i vlastitim osjećajima $(M=3,1, \mathrm{sd}=0,97)$. Ne smatraju ga beskorisnim $(\mathrm{M}=1,49, \mathrm{sd}=0,75)$, niti im je neugodno $u$ nekim situacijama koristiti lokalni govor $(M=1,31$, $\mathrm{sd}=0,68)$, a preferiraju ga u razgovoru s prijateljima $(\mathrm{M}=2,75, \mathrm{sd}=1,22)$. Ovo izravno ispitivanje jezičnih stavova pokazalo je da mladi u Makarskom primorju niti splitski, a još manje zagrebački, urbanolekt ne vide kao prestižan jezični izraz $(M=1,70, \mathrm{sd}=0,9$ za splitski te $\mathrm{M}=1,33, \mathrm{sd}=0,71$ za zagrebačkim). Sve navedene vrijednosti predstavljaju srednju vrijednost odgovora dobivenih na Likertovoj skali od 1 (nimalo) do 4 (potpuno).

Kruskal-Wallisov test pokazuje da ipak postoje statistički značajne razlike u pojedinim segmentima jezičnih stavova među ispitanicima s obzirom na a) mjesto rođenja i b) porijeklo. To se odnosi na a) ponos prema lo- 
kalnom govoru $\left(\chi^{2}=14,07, \mathrm{p}=0,001 \mathrm{~s}\right.$ obzirom na mjesto rođenja, odnosno $\chi^{2}=8,57, \mathrm{p}=0,036 \mathrm{~s}$ obzirom na porijeklo oca), b) nelagodu zbog korištenja lokalnog govora $\left(\chi^{2}=6,11, p=0,047 \mathrm{~s}\right.$ obzirom na mjesto rođenja i $\chi^{2}=9,70, p=0,021 \mathrm{~s}$ obzirom na porijeklo majke). Pritom mladi rođeni $\mathrm{u}$ Makarskome primorju $(\mathrm{N}=304)$ ili izvan Hrvatske $(\mathrm{N}=8)$ više vrednuju lokalni govor, $\mathrm{tj}$. ponosniji su na njega $(\mathrm{M}=3,35, \mathrm{sd}=0,85$ za rođene $\mathrm{u}$ Makarskom primorju i $\mathrm{M}=3,62$, $\mathrm{sd}=0,52$ za rođene izvan $\mathrm{RH}$ ) i rjeđe se ustručavaju govoriti ga $(M=1,29, \mathrm{sd}=0,67$ za rođene $\mathrm{u}$ Makarskom primorju i $\mathrm{M}=1,25, \mathrm{sd}=0,46$ za rođene izvan $\mathrm{RH}) \mathrm{u}$ odnosu na one rođene drugdje u Hrvatskoj $(\mathrm{M}=2,67$, sd = 0,84, odnosno $\mathrm{M}=1,67$, sd =0,91). Osim toga, statistički je značajna razlika između triju grupa ispitanika i s obzirom na tolerantnost prema jezičnoj raznolikosti $\left(\chi^{2}=8,58, p=0,014\right.$ s obzirom na mjesto rođenja), pri čemu unificirani govor na razini države najmanje poželjnim smatraju učenici rođeni izvan $\mathrm{RH}(\mathrm{M}=1,88, \mathrm{sd}=1,13)$, a najpoželjnijim učenici iz drugih dijelova $\mathrm{RH}(\mathrm{M}=3,17, \mathrm{sd}=1,10)$.

Zbog vrlo neujednačene veličine pojedinih grupa s obzirom na mjesto rođenja, bilo je potrebno provjeriti i koju ulogu porijeklo učenika igra u formiranju jezičnih stavova dobivenih njihovim direktnim istraživanjem. S obzirom na to da je Makarsku, ali i čitavo područje, najveći val doseljavanja zahvatio 90-ih i početkom 2000-ih, grupa mladih »rođenih u Makarskom primorju « čini i velik broj onih čiji su roditelji doselili iz drugih dijelova RH ili susjednih država. Primjenom Kruskal-Wallisovog testa porijeklo oca pokazalo se relevantnim za razlike među mladima s obzirom na osjećaj ponosa zbog vlastitog govora, ali i odnos prema ideologiji jezične ispravnosti $\left(\chi^{2}=10,95, p=0,012\right)$ i posebno odnos prema uporabi standardnog varijeteta na nastavi $\left(\chi^{2}=10,79, p=0,013\right)$. Ako djeca očeva rođenih $u$ Makarskom primorju osjećaju najviše ponosa zbog lokalnih govora $(\mathrm{M}=3,46$, $\mathrm{sd}=0,73)$, što ispravnije trude se govoriti djeca očeva rođenih drugdje $\mathrm{u}$ Dalmaciji $(\mathrm{M}=2,47, \mathrm{sd}=1,08)$ i onih rođenih izvan $\mathrm{RH}(\mathrm{M}=2,48$, $\mathrm{sd}=1,02)$. Istim je testom potvrđena statistički značajna razlika s obzirom na tendencija prema "ispravnom" govorenju ovisno o mjestu rođenja sudionika $\left(\chi^{2}=10,88, p=0,004\right)$, odnosno mjesto rođenja majke $\left(\chi^{2}=10,60\right.$, $\mathrm{p}=0,014)$ pri čemu sklonost prema "ispravnom" govoru pokazuju ponajviše mladi rođeni $u$ drugim dijelovima Hrvatske $(M=2,94, s d=0,94) i$ oni izvan $\mathrm{RH}(\mathrm{M}=2,76, \mathrm{sd}=1,28)$ kao i mladi čije su majke rođene izvan $\mathrm{RH}(\mathrm{M}=2,84, \mathrm{sd}=1,02)$ ili drugdje u RH (ali ne u Dalmaciji, $\mathrm{M}=2,77$, $\mathrm{sd}=1,10)$.

U kvalitativnom dijelu istraživanja samo su dvije učiteljice razredne nastave eksplicitno govorile o jezičnim stavovima svojih učenika te smatraju da su oni pozitivni prema lokalnom, odnosno »dalmatinskom«, govoru. 
Lucija Šimičić, Marija Ćubelić: Između standardnog varijeteta i lokalnih govora...

FILOLOGIJA 76(2021), 201-251

I: Imaju li djeca razvijenu svijest da Makarsko primorje ima svoj neki govor i u čemu se sastoji?

S5: Imaju, to oni nazivaju dalmatinski, oni su vam jako ponosni, dalmatinski govor, bila boja. Dalmatinski. Naš lipi dalmatinski govor [...] svjesni su oni da je Makarsko primorje opet posebno u svemu, ali sad da su nešto previše to nisam baš primijetila. (Marija)

Ja mislim da moji učenici imaju baš pozitivan stav prema tom zavičajnom govoru. (Olga)

Za razliku od dviju učiteljica razredne nastave, iz razgovora s nastavnicama Hrvatskoga jezika proizlazi da je jezična osviještenost među starijim osnovnoškolcima nedovoljno razvijena u odnosu na standardni varijetet, osim u pogledu ranije spomenutih obilježja, ponajviše ikavštine (v. 6. 3.). Također, termin dalmatinski koji većina ispitanika navodi kao naziv svog prvog jezika, ne podrazumijeva nužno jezičnu identifikaciju s čitavom Dalmacijom što je nekoliko sugovornika pojasnilo $u$ intervjuu. Naime, ranija su istraživanja jezičnih stavova korištenjem neizravne tzv. verbal guise metode pokazala da mladi većinom najprestižnijima smatraju lokalne urbane govore (Šimičić-Sujoldžić 2004, Sujoldžić 2008, Sujoldžić-Šimičić 2013). Upravo se zato jedan od aspekata jezičnih stavova koje smo obuhvatile $\mathrm{i}$ ovim istraživanjem odnosio na razumijevanje percepcije statusa $\mathrm{i}$ utjecaja splitskog urbanolekta u Makarskome primorju i eventualne promjene te percepcije među govornicima različitih generacija. Bez obzira na to što i podaci prikupljeni upitnicima pokazuju da sudionici većinom svoj govor nazivaju dalmatinskim, niske srednje vrijednosti pri vrednovanju splitskog govora kao uzora među mladima dobivene upitnikom, dodatno su potvrđene $u$ intervjuima. $U$ njima većina naših sugovornika naglašava jasno distanciranje mladih u Makarskome primorju ne samo u odnosu na zagrebački govor jer im je dalek i većinom nerazumljiv (»Zagreb im je dalek, to je njima kao mi njih ništa ne razumijemo, pa ono... znalo se čuti... svašta to oni govore bum, buš mi ne razumijemo, znate ono (smijeh), bum bude i tako.«, Marija) već i u odnosu na njima mnogo bliži splitski govor.

Možda im splitski imponira na neki način, ali isto sam evo čula par komentara dok sam slušala: »A oni Splićani oni razvlače brale, e nije im to baš ono«. (Sanja)

Iako sjeverni dio Makarskog primorja gravitira Splitu u različitim domenama te se mnogi mladi identificiraju s određenim društvenim, kulturnim i sportskim segmentima života u Splitu, govor većinom smatraju vrlo različitim od vlastitoga i jezično se s njime ne poistovjećuju.

Split im je najviše zbog Hajduka [...] tome gravitiraju. (Marija) 
Nitko od sugovornika ne smatra da mladima u Makarskom primorju neki određeni urbanolekt predstavlja prepoznatljiv uzor. Na upit o govoru koji mladi u Makarskoj smatraju prestižnim, Sanja ističe da je to prije svega sleng koji obiluje anglizmima kao i određenim tipičnim adrijatizmima.

S3: Ja bi rekla engleski. Od naših govora ništa. A od naših govora imaju oni neki svoj žargon, to nije uopće više taj baš makarski neki nego je to više ono po njihovoj dobi, kako se to ono kaže?

\section{I: Sleng neki ?}

S3: E da to! Baš to, ala sleng. To je njima najprestižnije i ti neki izrazi koje samo oni koriste i razumiju. Već meni nerazumljivi. [...] njihov ideal je taj neki miks ikavskog govora i tih nekih slengovskih izraza. (Sanja)

Upravo neočekivano jezično kombiniranje riječi stranoga porijekla koje su u morfosintaktičkom smislu često neadaptirane ili tek parcijalno adaptirane $\mathrm{u}$ hrvatski jezik s određenim pozitivno vrednovanim lokalnim jezičnim obilježjima, svjedoči o važnosti jezičnih prijelaza (Rampton 2006, 2009) i općenito transjezičnih praksi (García 2009) kao ključnih u formiranju i iskazivanju posebnog identiteta. Taj je identitet istovremeno lokalan i globalan, izdvojen od urbanolekata najbližih većih urbanih sredina, ali zadržava obilježja dalmatinskog regiolekatskog koinea (usp. Skelin Horvat 2017). Govor mladih u Makarskome primorju na taj način predstavlja kontinuitet govora starije generacije govornika makarskih govora, no unosi u njega i jezične novitete koji im omogućuju formiranje novog posebnog identiteta u lokalnom kontekstu. ${ }^{6}$

Bilo kakvo jezično isticanje koje nije u skladu s gore opisanim praksama nerijetko je izloženo ismijavanju ili, rjeđe, otvorenom ruganju. U kvantitativnom je dijelu istraživanja, na temelju testiranja pomoću Kruskal-Wallisovog testa, utvrđeno da je porijeklo majke relevantna varijabla u tom kontekstu $\left(\chi^{2}=9,80, p=0,02\right)$. Prema navodima odraslih sugovornika u kvalitativnom dijelu istraživanja, djeca pokazuju manjak tolerancije prema govorima koji odudaraju od njihovog govora ili govora koje povezuju s Makarskim primorjem. ${ }^{7}$ Sugovornici u ponašanju među djecom prepoznaju

6 Način oblikovanja njihovih specifičnih transjezičnih praksi, tj. jezičnih obilježja koja se u tom procesu zadržavaju i onih koja se gube, zahtijeva opširniju analizu koja nadilazi okvire ovoga rada.

7 Zanimljivo je da odgovornost ne pripisuju vlastitom ponašanju, odnosu prema nestandardnim govorima u obrazovnom kontekstu, već nekome drugome, samim svojim postojanjem, a nerijetko im se pripisuje i nametanje i jezična prodornost. U samo jednom razgovoru sugovornik je takvo stanje povezao s povijesnom orijentiranošću stanovništva BiH prema Makarskom primorju kao turističkoj destinaciji te višedesetljetnom jezičnom prilagodbom ondašnjeg stanovništva velikom broju turista. 
jezičnu distancu u odnosu na njima bliske otočne govore pa čak i one štokavske (»I to bi vam bila nekako mala netrpeljivost između onih koji su došli i ovih domaćih «, Gordana), no ona je zamjetnija u odnosu na doseljenike sa sjevera i iz unutrašnjosti čak i kada se radi o govorima došljaka iz Bosne ili Hercegovine koji su u Makarskom primorju široko zastupljeni.

Neće se rugati nitko njemu koji govori dijalektom makarskim, a ne standardnim. Bilo koji izraz koji upotrijebiš je ono svima normalan, ali te neke drugačije naglaske i dijalekte sa strane tooo je već njima razlog za... (Sanja)

I: A jesu oni međusobno tolerantni prema govoru drugih?

S5: Pa neki miks ovako, ako je... inače ako su roditelji odselili iz Bosne ili je dijete od tamo kaže: došo, prošo to je njima jako smiješno. To već ide izrugivanje ovima ovdje. A ovima opet bude smiješno, ovi koji su došljaci, njima opet bude smiješno stari makarski izraz, kad kaže lancun, ponistra, katriga... (Marija)

Prema navodima naših sugovornika, mnogi osnovnoškolci ne pokazuju toleranciju prema govorima došljaka, no lokalna jezična obilježja također tek djelomice prihvaćaju ovisno o tome radi li se o obilježjima koja su dijelom jezičnih repertoara njihovih vršnjaka. Ikavštinu i pojedine romanizme prihvaćaju čak i ako ih sami ne koriste, no manje su tolerantni prema obilježjima lokalnih govora koja percipiraju kao arhaična ili ruralna.

\subsection{Upravljanje jezikom u obrazovnom procesu}

Svaki oblik upravljanja jezikom složen je i višeslojan. U odgojno-obrazovnom sustavu ta se višeslojnost očituje u diskursima koji se oblikuju i promiču nacionalnim službenim dokumentima (strategijama, kurikulima, nastavnim planovima i programima i sl.), na lokalnoj i regionalnoj razini (posebice u višejezičnim sredinama) kao i na razini svake pojedine škole. Svi se ti diskursi konačno materijaliziraju u razrednom kontekstu u kojem nastavnici učenicima postavljaju pravila prihvatljivog jezičnog ponašanja. Iako je nacionalni okvir načelno otvoren prema njegovanju »zavičajnih govora «, barem na diskursnoj razini, već je na ovoj razini očita preferencija prema standardnojezičnom izrazu kao što smo pokazale u dijelu 3. 2. Takav se stav dodatno promiče i u programima za obrazovanje učitelja i nastavnika Hrvatskog jezika na sveučilišnoj razini (Jelaska 2002a, Jelaska 2002b, Miškulin Saletović i sur., prihvaćeno). Ta se nesigurnost u pogledu odnosa prema nestandardnim varijetetima prenosi i u razrede. Razgovori s našim sugovornicima koji su mahom i sami djelatnici u odgojno-obrazovnom sustavu nerijetko odražavaju konfliktne diskurse o poželjnom odnosu prema standardnom varijetetu i »zavičajnim govorima", posebno nelokalnim zavičajnim govorima (Turza-Bogdan 2009), dok se o 
drugim tipovima nestandardnih varijeteta manje uči u školama. Diskursi koji proizlaze iz dubinskih intervjua koje smo vodili s nastavnim osobljem u školama Makarskoga primorja temelje se na dvjema različitim, no ne nužno i suprotstavljenim, jezičnim ideologijama: a) ideologiji standardnog jezika i b) ideologiji jezika kao baštine.

Ideologija standardnog jezika (Lippi Green 1997, Milroy 2001) duboko je usađeno uvjerenje da je standardni varijetet jedini ispravan i prihvatljiv u formalnim domenama, uključujući obrazovne ustanove, obveznu nastavu, razredno ili školsko okruženje. Tollefson (1991) naglašava da su upravo obrazovne institucije kao jedno od mjesta ideološke produkcije (Silverstein 1998:136) ključne (no ne i jedine) u promicanju ideologije standardnog jezika, a i naši sugovornici potvrđuju da mladi jezičnu ispravnost poistovjećuju sa školskim okruženjem.

I: A gdje se onda u Hrvatskoj govori najispravnije? Da li oni uopće imaju tu ideju?

S1: Oni će vam reći u školi.

I: Aha, znači u školi. Ne geografski točno nego...

S1: ... jer se u školi to uči, ono što u školi uče, hrvatski književni jezik, to u pravilu. (Gordana)

Ideologija standardnog jezika legitimizira prakse kojima se u samom nastavnom procesu svi ostali varijeteti (hrvatskoga jezika) brišu. U hrvatskom je formalnom obrazovanju prisutnost ove ideologije očita već i u samom nazivu predmeta $\mathrm{u}$ kojem se hrvatski jezik prvenstveno odnosi na njegov standardni varijetet, a tek marginalno tolerira zastupljenost drugih varijeteta hrvatskog jezika u sklopu nastave (v. 3. 2.). Ovakav je oblik ideološkog brisanja (Gal-Irvine 1995) određenih jezičnih oblika i varijeteta prisutan u nastavnim praksama čak i onih nastavnika koji i sami gaje pozitivan stav prema lokalnim govorima i dijalektima općenito. Standardnojezična ideologija, ne samo da teži jasnom razgraničavanju standardog od ostalih nestandardnih varijeteta, već ove druge potiskuje ograničavanjem njihove uporabe na a) izvannastavne školske aktivnosti ili, kod manjeg broja nastavnika, i na b) neformalne vidove nastavnog procesa. Kao učiteljica razredne nastave Gordana ih, na primjer, i sama rabi izvan školskog okruženja, no inzistira na usađivanju standardnojezične ideologije kod djece već od samog početka odgojno-obrazovnog procesa.

[...] uobičajeno je kad imamo - na lokalnom govoru piše više nekako da je na izvannastavnim aktivnostima kad imamo literarnu skupinu onda oni više rade na tome, na lokalnom jeziku, lokalnom govoru. (Marija)

[...] provodim te radionice vezane uz materinski jezik i iz tih radionica mi 
Lucija Šimičić, Marija Ćubelić: Između standardnog varijeteta i lokalnih govora...

FILOLOGIJA 76(2021), 201-251

dolaze neki radovi koji budu prepoznati i budu na natjecanju Lidrano. (Dijana)

A ja vam njima pričam, oni znaju razliku da je književni jezik - i imamo mi i književni jezik i zavičajni govor [...] I oni znaju da je književni jezik na satu i da se oni tako moraju izražavati. A čim iziđemo na dvorište vanka škole mi smo dijalekt. Znaju da ću ja pričat ikavicom i oni pričaju ikavicom i ja ih motiviram da kući njeguju ikavicu. Da je njeguju, zavičajni govor. [...] A ja kažem vi kada dođete u školu vi ćete pričat književnim jer morate. (Gordana)

S1: Vidite kad radimo nešto neformalno, govorimo ovim dijalektom, e a kad je čista nastava to je to.

I: Onda, znači, ne biste ispravljali djecu?

S1: Ne ma ni slučajno to mi ne pada na pamet. Ne pada na pamet, pa to je bogatstvo, zavičajni govor. (Gordana)

Marija smatra usvajanje i uporabu lokalnih govora u obrazovnoj ustanovi prikladnima jedino u sklopu izvannastavnih aktivnosti. Gordana, s druge strane, unatoč ustrajanju na isključivom korištenju standardnog varijeteta hrvatskog jezika na nastavi, pa čak i u sklopu nastave koja je manje usmjerena na usvajanje jezičnih znanja i vještina, povremeno dopušta korištenje lokalnog, tzv. zavičajnog govora u nastavi, odnosno ne ispravlja uvijek djecu koja upotrebljavaju lokalizme. Iako Olga vrlo aktivno potiče učenike nižih razreda da usvajaju lokalni leksik tijekom aktivnosti organiziranih izvan nastave, te i tijekom nastave nastoji promicati pozitivan stav na razini diskursa, i ona ustraje na strogom razdvajanju različitih varijeteta istoga jezika.

S2: Pa oni točno znaju da govorimo književnim govorom, a zna se kad pišemo sastavak na zavičajnom govoru, ali točno se zna razlika što je što i ne miješamo to.

I: A na likovnom, glazbenom, tjelesnom?

S2: Uvijek se na satu trudimo govoriti književnim jezikom, ali uvijek se spomene da je lijepo što zna koristiti te riječi i da mogu tako govoriti kad su kod kuće i u slobodno vrijeme, al da u školi i u razredu govorimo književno. (Olga)

Ovo je tek jedan od iskaza u kojima naši sugovornici na diskurznoj razini pokušavaju pomiriti suprotstavljene stavove koje u praksi dva varijeteta istog jezika nastoje jasno razgraničiti u uporabi svojih učenika. Svjesni da zabrana uporabe bilo kojeg osim standardnog varijeteta na nastavi vodi do jačanja negativnih stavova prema njima barem na podsvjesnoj razini, nepoželjne učinke takve prakse nastoje ublažiti na verbalnoj razini. Međutim, implicirano hijerarhiziranje standardnog i "zavičajnog" varije- 
teta, pri čemu se naglašava da je samo prvi legitiman u instituciji koju djeca poistovjećuju s "ispravnim" oblikom jezika, još je jedan vid ranije spomenutih konfliktnih diskursa koji pogoduje razvijanju jezične nesigurnosti kod učenika.

Ima i toga. Može i to bit - je je, to kao nije dobro, to ispravi ... samo što moram ispravljati jer to se kao šalje poruka to nije dobro, makni to - čisti jezik ono. Ja sam za to da se njeguju lokalni govori, zavičajni govor i standard. (Marija)

Tome doprinosi ograničavanje dozvoljene uporabe lokalnih varijeteta čime njihova prihvatljiva uporaba nerijetko poprima obrise performansa.

S1: [...] pošto sam ja možda više neka tradicionalna osoba i u jeziku, kad sam u razredu pričam hrvatskim književnim jezikom, a to i tražim od djece.

I: Na svim predmetima?

S1: Na svim predmetima tražim književni. [...] I od njih tražim da se tako izražavaju. Međutim onaj drugi dio koji ja izričito njegujem kod njih to je zavičajni govor. Imamo temu zavičajnog govora kroz književnost $i$ onda u taj zavičajni govor uključujem i obitelji. Tamo gdje znam da su baka, dide, obitelj domaća i da pričaju zavičajnim govorom kući tada im na sat pozivam roditelje, babe, dide svi koji žele pričat da nam kažu kako se to govorilo prije kako je izgledalo, na koji način oni komuniciraju doma.

I: Na satove hrvatskoga ili imate neke posebne...?

S1: ... i na satove hrvatskog i pozvala bih kad oni mogu. Uklopili bi to uglavnom to bi nam bio cijeli projekt. [...] I tako bi ja njih pozvala na sat i oni bi pričali u tom starom žargonu i kako bi se to onda prevelo na književni. Onda bi im dala tekst na književnom jeziku, neku pjesmu da je prevedu na zavičajni govor, onda sa zavičajnog govora da je prevedu na književni tako da bi sve zastupili. (Gordana)

Iz prvog ulomka proizlazi da je zastupljenost nestandardnih varijeteta $\mathrm{u}$ nastavnom programu rijetka te jasno vremenski i tematski omeđena što omogućuje aktivno uključivanje starijih članova obitelji učenika. S obzirom na način na koji je prezentiranje zavičajnih govora prikazano u diskursu »kako se to govorilo prije«, učenicima se uz već spomenutu i prevladavajuću standardnojezičnu ideologiju istovremeno usađuje i ideologija jezika, u ovom slučaju lokalnih govora, kao baštine. Jezik se na taj način okamenjuje kao tradicija, nasljeđe i znanje koje posjeduju stari, a mladi ga mogu samo pasivno upijati, dokumentirati bilježenjem zaboravljenog leksika, izraza i poslovica. Jedina mogućnost aktivne i kreativne uporabe lokalnih govora u nastavi ograničena je na rijetke zadatke u kojima se od učenika traže pisani radovi, najčešće sastavci ili pjesme. 
Lucija Šimičić, Marija Ćubelić: Između standardnog varijeteta i lokalnih govora...

FILOLOGIJA 76(2021), 201-251

Ja ih i često puta zamolim da napišu nešto na zavičajnom govoru. Ovdje u Makarskoj to i nije baš makarski, to vam je baš neka mješavina, svega uzmu... (Marija)

Iako se radi o oblicima izražavanja koji u kontekstu lokalnih govora predstavljaju stilizaciju koju bi tek rijetki poznavatelji lokalnih govora mogli realizirati, jer je i u prošlosti pisano izražavanje na lokalnim govorima bilo tek iznimno, nastavnici mahom zaključuju da većina današnjih mladih ne poznaje ni vlastiti govor.

Za marginalizaciju lokalnih govora u samom procesu nastave naši sugovornici, uglavnom nastavnici Hrvatskoga jezika ili učitelji razredne nastave, navode i niz objektivnih okolnosti koje ih onemogućavaju u nastojanju da lokalne govore aktivnije uvedu u nastavni proces.

A mi samo koliko možemo, da. Ja njima ističem to da je važno njegovati svoj lokal- mjesni govor i govor Makarskoga primorja, ali nemam vremena. [...] A pretrpan nam je program, stvarno nema se puno vremena, ali ovo što radimo uvijek možemo malo dotaknut, znate. Tako da... ili ovo što sam rekla kroz izvannastavne aktivnosti, sekcije pa da onda djeca koja su zainteresirana. Ima njih koji vole, jako vole pisati kao [ime] - ha sad jel to makarski govor, kažem ja nisam primijetila da oni nešto posebno znaju njega. [...] Oni kao da svega malo, znate, od svega malo uzmu i - ali trude se, trude govoriti književnim jezikom. (Marija)

Ako su neki od razloga za izmještanje nestandardnih varijeteta iz nastavnog procesa prenatrpan plan i program te manjak vremena (jedna nastavnica navodi svega tri do četiri sata godišnje po razredu) kao i već spomenuto nepoznavanje (određenih) lokalnih govora, kako od strane nastavnika tako i učenika, neki nastavnici nastoje taj uočen nedostatak bavljenja zavičajnim govorom nadomjestiti tolerantnijim stavom prema njihovoj povremenoj uporabi u učionici.

I: Kako vi onda reagirate kad tako bilo pišu bilo se izražavaju na hrvatskom, je li ih ispravljate uvijek ili samo ponekad ili...?

S2: Ja ih nastojim uvijek ispravljat standardnom riječi, a u pisanju isto, da. $\mathrm{Al}$ ako je neka stara makarska, al to je rijetko, taj ima stilsko pravo i ostavim tu riječ. (Marija)

Jasno je, međutim, da je jezična tolerancija na nastavi vrlo selektivna jer se $u$ većini slučajeva radi o njegovanju i vrednovanju isključivo geografskih i to lokalnih varijeteta, dok su istovremeno ostali oblici jezične varijabilnosti i dalje u potpunosti marginalizirani kao nepoželjni. Selektivnost je prisutna i u odabiru jezičnih elemenata čije se očuvanje potiče i koji se većinom svode na leksičku razinu, dok njegovanje i očuvanje obilježja lokalnih govora na ostalim jezičnim razinama nitko od sugovornika nije spomenuo. 
Lucija Šimičić, Marija Ćubelić: Između standardnog varijeteta i lokalnih govora...

FILOLOGIJA 76(2021), 201-251

S druge strane, nastavnici naglašavaju i prilično visok stupanj fleksibilnosti postojećih planova i programa koji im omogućavaju slobodu u izboru, količini vremena i načinu obrade tzv. zavičajnih sadržaja.

Ja osobno uvijek kažem dajte mi vi neki okvirni program, nacionalni jel tako, i unutar toga nek se mene pusti na miru. Ja sad govorim za sebe. Nek me se pusti da ja onda radim što mislim da je i važnije i bolje i ljepše i tako. Mislim da je važno njegovati zavičajni govor. To je naše obilježje. To smo mi. Jezik to smo mi. (Gordana)

Ovakvu dozu slobode u planiranju nastave pa i uvođenju tema vezanih uz nestandardne varijetete prepoznaju učitelji razredne nastave te $\mathrm{u}$ manjoj mjeri nastavnici Hrvatskoga jezika u višim razredima osnovne škole.

Hrvatski jezik sa sedmim i osmim razredom imam četiri sata tjedno i ništa mi nije zadano od književnosti pa ću ja prilagodit [...] kad pišem plan i program [...] znači, ko zna i ko planira, može. (Dijana)

S1: Vidite ovako [...] po planu i programu [je da] ako vi želite ako vam je to važno vi ovo sve možete provuć. Sve to možete provuć kroz gradivo. Znači vi kada...

I: ... znači kako plan i program dozvoljava da lokalni ili regionalni govori budu zastupljeni?

S1: Ma mogu, zavisi koliko vi želite. Ako vi ne želite neće vam biti zastupljeno ništa. Ako učiteljica nije odavde njoj to neće bit važno. A ne možete joj ni zamjerit ako to ne obradi. (Gordana)

Unatoč nastavnim praksama koje podržavaju i promiču ideologiju standardnog jezika kod učenika i uvođenju ideologije (zavičajnog) jezika kao baštine kao njene protuteže, većina su naših sugovornika i sami govornici nekog od govora Makarskog primorja te su svjesni da im prijeti nestanak zbog jezičnog niveliranja. Prijeteću zamjenu jezika većina ipak ne pripisuje institucionalnim jezičnim politikama, već je smatraju posljedicom migracija u lokalnim kontekstima te upliva stranih riječi (anglizama) kao posljedice utjecaja medija i, šire, globalizacijskih procesa.

I: Mislite li da su dijalekti dovoljno zastupljeni u obrazovanju općenito?

S1: Mislim da bi trebali više, a ovo je recimo moja dobra volja što je meni to važno i što ja tako radim. Mislim da bi im trebalo dati više prostora zato jer izumiru, ljudi koji su došli sa strane promijenili su sve. (Gordana)

Spomenut se manjak zanimanja za lokalne govore kao i nedostatna jezična kompetencija u tom segmentu temelje na nepoznavanju tradicionalnog leksika lokalnih govora. Dio naših sugovornika za takvo stanje odgovornima smatra brojnost i jezičnu neprilagođenost doseljenika, negativne stavove djece prema lokalnom govoru ili pak nekontroliran prodor anglizama i novotvorenica posredstvom medija. 
Za jezičnu nesigurnost dijelom su odgovorni i ostali dionici u jezičnoj socijalizaciji, posebno vršnjaci i obitelj. Naši sugovornici smatraju da vršnjačko ruganje zbog jezičnih razlika u Makarskom primorju ide nauštrb dalmatinskog govora, a ne obrnuto. Učiteljica razredne nastave uzrok tome vidi u miješanim i nedosljednim jezičnim obrascima u obitelji djece koja su, zbog toga, prijemčivija za strane utjecaje.

I: A mislite li da najviše na djecu utječu njihovi vršnjaci?

S1: Utječu jako. Utječe i obitelj.

I: A koliko?

S1: Dosta, dosta, recimo ja imam u mome razredu one koji su baš Makarani i mame i tate i babe i dide isto odavde. Takvima se neće dogodit da je napiso da je došo, pošo, da će prihvatit to odma. Pričaju pravilno, a tamo gdje su nesigurnija djeca gdje nisu baš sigurna u svoj nekako govor ili je to tu ili u kući kad se miša njima je lako pokupit sve. E, a ovi [doseljenici] vam teško minjaju sebe. Zato što se kući priča. Razumite? (Gordana)

S2: Mislim da su najodgovorniji roditelji jer to iz doma kreće. Što se tiče toga koliko znaju, ali ja mislim, ali ne mogu ja utjecati na roditelje, oni govore kako govore, a ja se trudim da ja uradim ono šta ja mogu. Ja mislim da je škola ta koja bi trebala to poticati, da se taj govor ne zaboravi,...

I: A ova škola...

S2: Naša škola kroz ovu [radionicu] i u redovnom programu imamo mi te redovne sate koji...

I: Meni se čini da u redovnom programu...

S2: To je minimalno [...] par sati, to je stvarno ništa, ali ovako kroz dodatni rad, to se može. (Olga)

Iako se većina nastavnika slaže u stavu da je način upravljanja jezikom u obitelji ključan za usvajanje, odnosno gubljenje lokalnih govora, smatraju da njihov odnos prema jeziku i jezičnim praksama koje nisu nužno u skladu s propisanim standardom također mogu pozitivno utjecati barem na jezične stavove njihovih učenika.

I: A imate li osjećaj da vi možete napraviti nešto više da djeca govore taj lokalni?

[...]

S3: Da im se otvori malo više prostora, ali ima uvijek prostora u izvannastavnim aktivnostima i svačemu nečemu ovaj, pa ono ukazivat na to da je to kul. Na način da kul profesorica njima prezentira mjesne izraze i da radimo natjecanja iz poznavanja tih izraza i tako te stvari, što su baš pokazali interes, [...] i mislim da će to urodit nekim plodom. (Sanja)

Oni su vam vrlo plastični, zavisi ako kući inzistiraju da se priča dijalektom 
Lucija Šimičić, Marija Ćubelić: Između standardnog varijeteta i lokalnih govora...

FILOLOGIJA 76(2021), 201-251

oni će vam pričat. Ako učiteljica nikad ne progovori dijalektom oni vam neće pričat dijalektom oni će pričat književnim jezikom. Mi smo tu jedan vrlo moćan medij - koja čudo čini - (Gordana)

Unatoč jednom dominantnom odnosu prema dijalektima i drugim nestandardnim varijetetima u nastavnom procesu, i među našim sugovornicima postoji višeglasje. Odnos prema lokalnim govorima i standardu dijelom je određen generacijski i ovisan o osjećaju ugroženosti (vlastitog) jezičnog identiteta, što je u mnogim slučajevima vezano uz društvenopolitičku klimu određenog razdoblja, a reflektira se na odnos prema jeziku, jezične prakse i prakse u podučavanju jezika.

I: Zanima me postoji li neka jasna, da li sad jezična politika, utjecaj škole ili...

S3: Meni o tome nitko nikad nije rekao [...] s kolegicom [ime] pogotovo pričam o tome, a ona dijeli moje mišljenje samo ona više koristi standardni. To je ta, ja sam je nazvala stara škola. Oni to malo više, onaj, potenciraju jer prema mome mišljenju, ovaj, kod njih je jezik zamišljen - da postoji jedna ispravna verzija kako bi rekla je li - ja ne mislim tako, po meni znate što je standard, ali nije ovo neispravno. (Sanja)

Upravo ova sugovornica pokazuje ponešto drugačiji stav prema korištenju lokalnih varijeteta (i) tijekom nastave:

S3: Ja stvarno mislim da to treba njegovati. Naravno treba povuć neku granicu gdje i kako se govori standardni. Ali ja ne forsiram učenike da to mora biti na svakom satu.

I: A gdje onda to mora?

[...]

S3: U nekome formalnom odgovaranju, ako mi on sada odgovara za ocjenu, znači kad ja postavljam neka pitanja, kad ga postavim baš ispravno kako treba onda on treba i odgovorit. A ako mi ovako pričamo, mi često nešto diskutiramo, onda ja dozvoljavam da se oni izraze - dozvoljavam. Dapače. (Sanja)

Takav stav proizlazi iz osviještenosti negativnih posljedica koje stalno ispravljanje ima na učeničke jezične repertoare jer

počnu mislit da tako kako oni govore nije dobro. Da mislim da dugoročno, htjela bih to izbjeć. Ja njih sad strogo ne ispravljam, nego već dobro sada smo na satu, sada smo u školi, sada bi trebalo reći, koristiti standardni jezik. Sve je to u redu, ti to govori tako, gdjegod ono, ali sada trenutno u ovoj prilici ti bi trebao se izražavati - ja moram znati da si ti svjestan da sad govoriš nekakvim govorom koji nije standardom, možeš li se izraziti standardnim da vidim, ja moram provjerit tvoje znanje, tako ja to njima nekako. Nije sad: »To ne to je sad krivo!«, ne to ne radim. (Sanja) 
S obzirom na to da je pozitivan jezični stav važan preduvjet očuvanja jezika te da negativan stav prema nedominantnom jeziku ili varijetetu predstavlja prekretnicu u nastojanjima da se očuva (Sasse 1992, Tsunoda 2005), vrednovanje nestandardnih govora čak i samo u izvanučioničkim aktivnostima poticanjem njihova usvajanja, a zatim i korištenja na nastavi, također može doprinijeti pobuđivanju većeg zanimanja za njih.

I: Koji je efekt [radionice] na djecu - počinju li upotrebljavati naučene riječi ili im se samo stav promijeni?

S2: Mislim da se stav svakako [promijeni], da to sigurno djeluje da se stav prema tome [govoru] mijenja, a ja osjetim ono kada govorimo nešto da neko izleti s nekom riječju s te [radionice], nešto pričamo pa se sjete kako je to baba Kate rekla. (Olga)

Kao i u slučaju povremenog toleriranja nestandardnojezičnih elemenata u nastavi, ali i drugim izvannastavnim aktivnostima u Makarskom primorju usmjerenima na njegovanje nestandardnih varijeteta, očita je selektivnost $\mathrm{u}$ odabiru tih varijeteta. Pritom se i u tako strogo definiranim kontekstima koji uopće dozvoljavaju odmak od uporabe standardnog varijeteta legitimnima smatraju tek "autohtoni" i "čisti" lokalni govori, dok nestandardni varijeteti koji predstavljaju odmak od takvog purističkog poimanja "zavičajnih" govora, ni u takvim kontekstima nisu prihvatljivi.

\section{Zaključak}

Oslanjajući se na tumačenje jezičnih politika kao kompleksnog fenomena koji obuhvaća upravljanje jezikom, jezične ideologije kao i same jezične prakse (Spolsky 2004, 2009) s ciljem reguliranja nekog jezika na razini strukture, uporabe i usvajanja (Cooper 1989), u ovom radu analiziramo jezične prakse osnovnoškolaca u Makarskom primorju. Ovaj se rad na taj način smješta u širi okvir zanimanja za analizu prihvatljivosti lokalnih govora i zastupljenosti nestandardnih varijeteta u obrazovanju, kao i utjecaja formalnoga odgojno-obrazovnog procesa na izgradnju i očuvanje postojećih jezičnih repertoara. $S$ obzirom na to da su jezične prakse duboko povezane s jezičnim stavovima, uvjerenjima o jeziku i jezičnim ideologijama koje se usađuju tijekom procesa socijalizacije i dodatno reproduciraju i osnažuju tijekom školovanja, u radu se osvrćemo i na konkretne primjere upravljanja jezikom i to posebno u kontekstu formalnog obrazovanja.

Na razini analize sociopsiholoških procesa koji oblikuju jezične prakse, utvrdili smo da mladi u Makarskom primorju na svjesnoj razini gaje pozitivne jezične stavove, iako vlastite govore tek iznimno identificiraju na mikrolokalnoj razini, pa čak i na razini Makarskog primorja. Za razliku od go- 
vornika lokalnih otočnih sredina (usp. Sujoldžić 2008, Šimičić 2011, Sujoldžić-Šimičić 2013), mladi u Makarskom primorju svoj govor najčešće nazivaju »dalmatinskim «, no istovremeno ga jasno distanciraju od govora drugih gradskih sredina u Dalmaciji, posebice od splitskog urbanolekta koji ne smatraju prestižnim, što također odudara od nalaza dosadašnjih istraživanja jezičnih stavova mladih u Hrvatskoj (Šimičić-Sujoldžić 2004, Sujoldžić 2008, Sujoldžić-Šimičić 2013). Pritom, međutim, kao posebnost vlastita govora svi ističu isključivo i inače vrlo raširena jezična obilježja ikavicu i poneki adrijatizam. Odrasli, u ovom slučaju nastavnici, primjećuju da mladima prestižni kod predstavlja kombinacija dalmatinskog koinea i mladenačkog slenga koji obiluje anglizmima, a govor većine taj ideal i odražava.

Imajući u vidu činjenicu da je svaki oblik upravljanja jezikom višeslojan te da ga oblikuje niz dionika na različitim razinama društvene strukture, koji ne moraju uvijek djelovati unisono, u radu prikazujemo neke vidove složenosti upravljanja jezikom u odgojno-obrazovnim ustanovama u lokalnom kontekstu. Unatoč nekim pozitivnim pomacima u podizanju svijesti o postojanju lokalnih varijeteta kao i njihovoj vidljivosti u javnosti u posljednjih tridesetak godina $u$ odnosu na ranije razdoblje, ovdje prikazana analiza odnosa nastavnika, ali i cjelokupne jezične politike prema različitim varijetetima hrvatskog jezika na nastavi Hrvatskog jezika kao i u odgojno-obrazovnom okruženju općenito ukazuje na niz paradoksa i sukobljenih diskursa (usp. Bratulić i sur. 2017). Već je na razini službenih dokumenata naizgled tolerantan odnos prema tzv. zavičajnim govorima, zasjenjen isticanjem nužnosti i potrebe usvajanja (isključivo) hrvatskoga standardnog jezika (MZOŠ 2006, MZOŠ 2011, MZO). Terminološka neujednačenost, primjerice nazivanje nestandardnoga varijeteta koji je idiom učenika zavičajnim govorom, zavičajnim idiomom, mjesnim govorom, dijalektom, također prikazuje nedefiniranost unutar diskursa koji se, u različitim oblicima, prenosi i u sam nastavni proces. Nitko od sugovornika u ovome istraživanju nije iskazao barem načelno negativan stav prema jezičnoj raznolikosti, a posebice prema potrebi očuvanja lokalnih govora. Svejedno, izmještanjem svih oblika nestandarnojezičnih izraza, pa tako i lokalnih govora, $\mathrm{u}$ izvannastavne kontekste (npr. izvannastavne aktivnosti, literarne skupine, razgovori s nastavnicima izvan prostora škole i sl.) ili u kontekste naglašenog performativnog karaktera (npr. predstave, festivali, obilježavanje kulturnih i/ili tradicionalnih običaja itd.), ti su govori neizbježno marginalizirani u cjelokupnom obrazovnom sustavu. Pokazale smo, međutim, da ima i onih nastavnika koji zastupaju drugačiji stav te u sam nastavni proces nastoje uklopiti i uporabu nestandardnih varijeteta. 
Lucija Šimičić, Marija Ćubelić: Između standardnog varijeteta i lokalnih govora...

Analiza diskursa lokalnih dionika te njihova kontekstualizacija s obzirom na službenu jezičnu politiku definiranu dokumentima na nacionalnoj razini dodatno otkriva napetosti i kontradiktornosti koje proizlaze iz nastojanja usklađivanja dviju u diskursima naših sugovornika najzastupljenijih jezičnih ideologija: ideologije standardnog jezika i ideologije jezika kao kulturne baštine. Pokazale smo da su one zastupljene čak i u diskursima onih nastavnika koji gaje pozitivan stav prema lokalnom govoru te ga sami rabe, visoko vrednuju i pod određenim se okolnostima zalažu za njegovo očuvanje. Unatoč tim nastojanjima, u obrazovnom je procesu i dalje prisutna snažna hijerarhizacija standardnog i nestandardnih varijeteta, pri čemu su zavičajni govori redovito marginalizirani vremenskim i tematskim ograničavanjem njihove uporabe $\mathrm{u}$ samoj nastavi te njihovim izmicanjem u sferu izvanškolskih ili barem izvannastavnih aktivnosti. Pojedini se nastavnici razlikuju s obzirom na osjećaj vlastite djelatne uloge (agentivnosti) u tom procesu. Dok neki, naročito učitelji razredne nastave, ističu mogućnost samostalnog utjecanja na jezične prakse, stavove i konačno formiranje jezičnih ideologija kod učenika, nastavnici se Hrvatskog jezika osjećaju ograničeniji u tom pogledu zbog nedostatka vremena, nedovoljne zastupljenosti tema, a time i mogućnosti posvećivanja tzv. zavičajnim temama. Jednima i drugima je zajedničko, međutim, da se u kontekstu ideologije jezika kao baštine, legitimnim smatra njegovanje isključivo jednog "zavičajnog" govora, i to prvenstveno posebnosti na leksičkoj razini, dok su ostali nestandardni varijeteti hrvatskoga jezika gotovo potpuno izbrisani (Gal-Irvine 1995) u kontekstu nastave Hrvatskog jezika i formalnog obrazovanja općenito.

U ovome smo radu analizu čimbenika koji utječu na očuvanje, odnosno gubljenje lokalnih govora, ograničile na prikaz ideologija koje se manifestiraju u diskursima dionika $\mathrm{u}$ formalnom obrazovanju na različitim razinama. Izdvajanje dviju ideoloških pozicija koje iščitavamo kako u službenim dokumentima tako i u nastavnoj praksi ne znači da su one jedini pa niti glavni razlog nestajanja lokalnih govora; zamjena jezika pa i svaka jezična promjena posljedicom su niza čimbenika od kojih je jezična politi$\mathrm{ka} u$ formalnom obrazovanju tek jedna u nizu. Važno je naglasiti da iščitavanje i detaljnija analiza dviju spomenutih ideoloških pozicija također ne znači da daljnjim širenjem istraživanja ne bi bilo moguće potvrditi i neke druge ideološke pozicije koje također u manjoj ili većoj mjeri sukreiraju jezičnu politiku u školama.

Kvantitativna analiza počiva na podacima temeljenim na samoizvješćivanju pa ih je potrebno i interpretirati imajući u vidu tu činjenicu. Teško je, na primjer, objasniti prebacivanje kodova između lokalnog i standardnog 
varijeteta s prijateljima samo s obzirom na to održava li se razgovor unutar učionice ili izvan školske zgrade kao što je nejasno kako je moguće da nešto manje od $20 \%$ djece na satovima Hrvatskog jezika s nastavnikom koristi isključivo lokalni varijetet. Jedno od pitanja koja se u tom kontekstu nameću jest i do koje su mjere mladi svjesni specifičnosti lokalnog govora u odnosu na standardni varijetet i kako definiraju granicu među njima. Ovo može biti posebno problematično jer su oba tipa varijeteta štokavski, a prema navodima sugovornika u kvalitativnom dijelu istraživanja, poznavanje je lokalnih idioma među mladima često ograničeno. Ako je granicu teško odrediti, postoji mogućnost da je barem dio odgovora uvjetovan ne stvarnim praksama, već naučenim pravilima jezičnog ponašanja. Iako smo tijekom provođenja upitnika više puta naglašavali važnost iskrenih a ne poželjnih odgovora, i dalje je moguće da dio odgovora sadrži usvojene i stoga normativne odgovore. U metodološkom je smislu istraživanje jezičnih politika i upravljanja jezikom u obrazovnom kontekstu nužno nadopuniti i promatranjem kao ključnom metodom prikupljanja podataka u etnografskim istraživanjima usmjerenima na dubinsko razumijevanje procesa koji oblikuju jezične ideologije, stavove i prakse govornika (Canagarajah 2006, McCarty 2011, Pérez-Milans-Tollefson 2018 itd.).

U sadržajnom pak smislu zanimanje za položaj i tretman nestandardnih varijeteta u obrazovanju u sociolingvističkim je istraživanjima u različitom intenzitetu prisutno još od šezdesetih godina prošloga stoljeća. U različitim formalnoobrazovnim kontekstima potvrđeno je pritom da upravo oslanjanje na nestandardne varijetete $u$ nastavnom procesu doprinosi ne samo aktivnijem sudjelovanju učenika, njihovom samopouzdanju i općenito boljem školskom uspjehu već i uspješnijem usvajanju standardnog varijeteta. Corson (2001) ipak naglašava nedostatak sinteze nalaza takvih istraživanja, a naročito njihove primjene u programima za obrazovanje nastavnika.

Povezujući analizu dokumenata u kojima je definirana službena jezična politika u hrvatskom osnovnoškolskom obrazovanju s jezičnim stavovima i praksama nastavnika koji tu politiku provode u svojim razredima, pokazale smo povezanost upravljanja jezikom u kojem se mikro- i makrorazine isprepliću predstavljajući kontinuum uvjerenja o jeziku kao i isprepletenost jezičnih stavova i praksi u poimanju lokalnog, regionalnog i nacionalnog identiteta. 


\section{Literatura}

Alerić, Marko; Tamara Gazdić-Alerić. 2009. Pozitivan stav prema hrvatskome standardnom jeziku kao uvjet njegova uspješnijega ovladavanja. Lahor: časopis za hrvatski kao materinski, drugi i strani jezik, 1/7, 5-23.

Auer, Peter; Frans Hinskens; Paul Kerswill. 2005. The Study of Dialect Convergence and Divergence: Conceptual and Methodological Considerations. Ur. Auer, Peter; Frans Hinskens; Paul Kerswill. Dialect change. Convergence and Divergence in European Languages. Cambridge: Cambridge University Press, 1-51.

Bayley, Robert; Ceil Lucas. 2007. Sociolinguistic Variation: Theories, Methods and Applications. Cambridge: Cambridge University Press.

Blažeka, Đuro. 2008. Kakvi tekstovi na narječju trebaju u nastavi hrvatskog jezika. Metodika, 9, 271-286.

Blommaert, Jan. 1999. Language ideological debates. Berlin - New York: Mouton de Gruyter.

Bouchard, Jeremie; Gregory Paul Glasgow (ur.). 2019. Agency in Language Policy and Planning: Critical Inquiries. New York - London: Routledge.

Bratulić, Ana; Siniša Smiljanić; Branka Drljača Margić; Tihana Kraš. 2017. Izazovi provedbe politike višejezičnosti u Hrvatskoj. Rasprave: Časopis Instituta za hrvatski jezik i jezikoslovlje, 43/1, 19-30.

Brozović, Dalibor. 1970. O Makarskom primorju kao jednom od središta jezično-historijske i dijalekatske konvergencije. Makarski zbornik, 1, 381405.

Busch, Brigitta. 2012. The linguistic repertoire revisited. Applied Linguistics, 33/5, 503-523.

Busch, Brigitta. 2017. Expanding the Notion of the Linguistic Repertoire: On the Concept of Spracherleben-The Lived Experience of Language. Applied Linguistics, 38/3, 340-358.

Canagarajah, Suresh A. 2006. Ethnographic Methods in Language Policy. Ur. Ricento, Thomas. An introduction to language policy: Theory and method. Malden - Oxford - Carlton: Blackwell, 153-169.

Cheshire, Jenny i dr. 1989. Dialect and Education in Europe: A General Perspective. Ur. Cheshire, Jenny; Viv Edwards; Henk Münstermann; Bert Weltens. Dialect and Education: Some European Perspectives. Clevedon - Philadelphia: Multilingual Matters, 1-10.

Corson, David. 2001. Language Diversity and Education. Mahwah, NJ: Lawrence Erlbaum.

Crystal, David. 2001. Language and the Internet. Cambridge: Cambridge University Press. 
Lucija Šimičić, Marija Ćubelić: Između standardnog varijeteta i lokalnih govora...

FILOLOGIJA 76(2021), 201-251

Dorian, Nancy. 1981. Language Death: A Life Cycle of a Scottish Gaelic Dialect. Philadelphia: University of Pennsylvania Press.

Duranti, Alessandro. 1997. Linguistic Anthropology. Cambridge: Cambridge University Press.

Fishman, Joshua. 1972. The Sociology of Language: An Interdisciplinary Social Science Approach to Language in Society. Rowley, MA: Newbury House.

Fishman, Joshua. 1973. Language modernization and planning in comparison with other types of national modernization and planning. Language in Society, 2 (1), 23-43.

Gal, Susan; Judith T. Irvine. 1995. The boundaries of languages and disciplines: How ideologies construct difference. Social Research, 62/4, 9671001.

Garrett, Peter; Nikolas Coupland; Angie Williams. 2003. Investigating language attitudes: Social meanings of dialect, ethnicity, and performance. Cardiff: University of Wales Press.

García, Ofelia. 2009. Education, multilingualism and translanguaging in the 21st century. Ur. Skutnabb-Kangas, Tove; Robert Phillipson; Ajit K. Mohanty; Minati Panda. Multilingual Education for Social Justice: Globalising the Local. Social justice through multilingual education. Bristol - Buffalo - Toronto: Multilingual Matters, 140-158.

Glasgow, Gregory Paul; Jeremie Bouchard (ur.). 2019. Researching agency in language policy and planning. New York - London: Routledge.

Gudelj-Velaga, Zdenka. 1990. Nastava stvaralačke pismenosti. Zagreb: Školska knjiga.

Gumperz, John J. 1964. Linguistic and social interaction in two communities. American Anthropologist, 66/(6/2),137-153.

Halilović, Senahid. 1996. Govorni tipovi u međurječju Neretve i Rijeke dubrovačke. Bosanskohercegovački dijalektološki zbornik VII, Sarajevo: Institut za jezik.

Hill, Jane H.; Kenneth C. Hill. 1986. Speaking Mexicano: Dynamics of Syncretic Language in Central Mexico. Tucson: University of Arizona Press.

Hraste, Mate. 1951. O štokavskim govorima na Hvaru i Braču. Zbornik radova Filozofskog fakulteta Sveučilišta u Zagrebu I. Zagreb: Filozofski fakultet Sveučilišta u Zagrebu, 379-395.

Hornberger, Nancy H.; David Cassels Johnson. 2007. Slicing the onion ethnographically: Layers and spaces in multilingual language education policy and practice. Tesol Quarterly, 41/3, 509-532.

Jaffe, Alexandra. 2007. Discourses of endangerment: Contexts and consequences of essentializing discourses. Ur. Duchêne, Alexandre; Monica Heller. Discourses of endangerment: Ideology and interest in the defence of languages. London - New York: Continuum, 57-75. 
Lucija Šimičić, Marija Ćubelić: Između standardnog varijeteta i lokalnih govora...

FILOLOGIJA 76(2021), 201-251

James, Carl. 1996. Mother tongue use in bilingual/bidialectal education: implications for Brunean Dwibahasa. Journal of Multilingual and Multicultural Development, 17, 248-257.

Jelaska, Zrinka. 2002a. Analiza programa nastave hrvatskog jezika na visokim pedagoškim školama. Ur. Kovačević, Melita; Dunja PavličevićFranić. Komunikacijska kompetencija u višejezičnoj sredini I: prikazi, problemi, putokazi. Zagreb: Naklada Slap, 48-51.

Jelaska, Zrinka. 2002a. Analiza programa nastave hrvatskog jezika na filozofskim fakultetima. Ur. Kovačević, Melita; Dunja Pavličević-Franić. Komunikacijska kompetencija u višejezičnoj sredini I: prikazi, problemi, putokazi. Zagreb: Naklada Slap, 52-54.

Jernudd, Björn H.; Das Gupta, Jyotirindra. 1971. Towards a theory of language planning. Ur. Rubin, Joan; Jernudd, Björn H. Can language be planned?: Sociolinguistic theory for developing nations. Honolulu: University of Hawai'i Press, 185-204.

Johnson, David Cassels. 2013. Language Policy. Houndmills: Palgrave Macmillan.

Kaplan, Robert B.; Richard B. Jr. Baldauf. 1997. Language planning from practice to theory. Clevedon: Multilingual Matters.

Kapović, Mate. 2006. Dijalekti, standard i sociolingvistički aktivizam. Ur. Granić, Jagoda. Zbornik HDPL-a 2005 - Jezik i mediji. Jedan jezik: višse svjetova. Zagreb - Split: HDPL, 375-383.

Kirshenblatt-Gimblett, Barbara. 2013. Svjetska baština i kulturna ekonomija. Ur. Hameršak, Marijana; Iva Pleše; Ana-Marija Vukušić. Preveo Mateusz-Milan Stanojević. Proizvodnja baštine: kritičke studije o nematerijalnoj kulturi. Zagreb: Institut za etnologiju i folkloristiku, 65-117.

Kurtović Budja, Ivana. 2009. Govori Makarskoga primorja - fonologija i morfologija. Doktorski rad. Zagreb: Filozofski fakultet Sveučilišta u Zagrebu.

Labov, William. 1969. The logic of non-standard English. Georgetown Monograph on Languages and Linguistics, 22, 1-44.

Lippi-Green, Rosina. 1997. English with an Accent: Language, Ideology and Discrimination in the United States. London: Routledge.

Lisac, Josip 2003. Hrvatska dijalektologija 1: Hrvatski dijalekti i govori štokavskog narječja i hrvatski govori torlačkog narječja. Zagreb: Golden marketing - Tehnička knjiga.

Listeš, Srećko; Linda Grubišić Belina. 2017. Kompetencijski pristup nastavi hrvatskoga jezika. Zagreb: Školska knjiga.

Lüdi, Georges; Bernard Py. 2009. To be or not to be...a plurilingual speaker. International Journal of Multilingualism, 6/2, 154-167. 
McCarty, Teresa. L. 2011. Introducing ethnography and language policy. Ur. McCarty, Teresa. Ethnography and language policy. London: Routledge, 1-28.

Milroy, James. 2001. Language ideologies and the consequences of standardization. Journal of Sociolinguistics, 5, 530-555.

Ministarstvo znanosti, obrazovanja i športa. 2005. Vodič kroz Hrvatski nacionalni obrazovni standard za osnovnu školu. Zagreb.

Ministarstvo znanosti, obrazovanja i športa. 2006. Nastavni plan i program za osnovnu školu. Zagreb.

Ministarstvo znanosti, obrazovanja i športa. 2011. Nacionalni okvirni kurikulum. Zagreb.

Ministarstvo znanosti i obrazovanja. 2019. Kurikulum nastavnog predmeta Hrvatski jezik za osnovne škole i gimnazije. Zagreb: Narodne novine.

Mišetić, Roko; Mario Bara. 2012. Stanovništvo Makarskog primorja: demografsko kretanje u vrtlogu društvenih promjena od 1945. do 2011. Ur. Mustapić, Marko; Ivan Hrstić. Makarsko primorje danas: Makarsko primorje od kraja Drugog svjetskog rata do 2011. Zagreb: Grad Makarska i Institut društvenih znanosti Ivo Pilar, 11-28.

Miškulin Saletović, Lucia; Emina Berbić Kolar; Klara Bilić Meštrić (u tis$\mathrm{ku}$ ). Multilingualism in Teacher Education in Croatia. Ur. Wernicke, Meike; Svenja Hammer; Antje Hansen; Tobias Schroedler. Multilingualism and Teacher Education: International Perspectives. Bristol: Multilingual Matters.

Nemeth-Jajić, Jadranka; Petra Prvulović. 2012. Zavičajni (čakavski) govor u razrednoj nastavi. Školski vjesnik: časopis za pedagoška i školska pitanja, 61/3, 289-304.

Niedzielski, Nancy A; Dennis R. Preston. 2000. Folk linguistics. Berlin New York: Mouton de Gruyter.

Nikočević, Lidija. 2012. Kultura ili baština? Problem nematerijalnosti. Etnološka tribina, 42/35, 7-20.

Papapavlou, Andreas; Pavlos Pavlou. 2005. Literacy and language-in-education policy in bidialectal settings. Current Issues in Language Planning, 6/2, 164-181.

Pavličević-Franić, Dunja. 2005. Komunikacijom do gramatike: razvoj komunikacijske kompetencije u ranome razdoblju usvajanja jezika. Zagreb: Alfa.

Pavličević-Franić, Dunja; Katarina Aladrović Slovaček. 2017. Mastering Croatian Standard Language in a Plurilingual School Environment. Croatian Journal of Education - Hrvatski časopis za odgoj i obrazovanje, 19/2, 61-74.

Pérez-Milans, Miguel; James, W. Tollefson. 2018. Language policy and planning: Directions for future research. Ur. Tollefson, James W.; Mi- 
Lucija Šimičić, Marija Ćubelić: Između standardnog varijeteta i lokalnih govora...

FILOLOGIJA 76(2021), 201-251

guel Pérez-Milans. The Oxford Handbook of Language Policy and Planning. Oxford: Oxford University Press, 727-744.

Peruško, Tone. 1961. Materinski jezik u obaveznoj školi: specijalna didaktika. Zagreb: Pedagoško-književni zbor.

Preston, Dennis. 1989. Perceptual Dialectology: Non-Linguists' Views of Areal Linguistics. Dordrecht: Foris.

Puljak, Lucija. 2011. Uloga zavičajnoga idioma u razvoju jezičnokomunikacijske kompetencije učenika mlađe školske dobi. Croatian Studies Review, 7/1, 293-305.

Rampton, Ben. 2006. Language in Late Modernity: Interaction in an Urban School. Cambridge: Cambridge University Press.

Rampton, Ben. 2009. Crossing, Ethnicity, and Code-Switching. Ur. Coupland, Nikolas; Adam Jaworski. The New Sociolinguistics Reader. New York: Palgrave Macmillan, 287-298.

Ricento, Thomas. 2000. Historical and theoretical perspectives in language policy and planning. Journal of sociolinguistics, 4/2, 196-213.

Ricento, Thomas. 2006. Theoretical Perspectives in Language Policy. Ur. Ricento, Thomas. An Introduction to Language Policy: Theory and Method. Malden, MA: Blackwell, 3-23.

Ricento, Thomas; Nancy Hornberger. 1996. Unpeeling the onion: Language planning and policy and the ELT professional. Tesol Quarterly, 30/3, 401-427.

Rješenje Ministarstva kulture Republike Hrvatske, 29. 11. 2019. https:// narod.hr/wp-content/uploads/2019/12/Rjesenje-\%C4\%8Da-kaj\%C5\%A1to-2019.pdf (pristupljeno: 18. 6. 2020.)

Sasse, Hans-Jürgen. 1992. Theory of language death. Ur. Brenzinger, Matthias. Language Death: Factual and Theoretical Explorations with Special Reference to East Africa. Berlin - New York: Mouton de Gruyter, 7-30.

Schmidt, Annette. 1985. Young people's Dyirbal: An example of language death from Australia. Cambridge: Cambridge University Press.

Schiffman, Harold. 1996. Linguistic Culture and Language Policy. LondonNew York: Routledge.

Shohamy, Elana G. 2006. Language policy: Hidden agendas and new approaches. London - New York: Routledge.

Silverstein, Michael. 1998. The Uses and Utility of Ideology: A Commentary. Ur. Schieffelin, Bambi B.; Katharyn A. Woolard; Paul V. Kroskrity. Language Ideologies: Practice and Theory. Oxford - New York: Oxford University Press, 123-145.

Skelin Horvat, Anita. 2017. O jeziku i identitetima hrvatskih adolescenata. Zagreb: Srednja Europa. 
Skelin Horvat, Anita; Lucija Šimičić. 2017. Micro-level perceptions of macro-level language management in Croatia. Ur. Ureland, Sture P.; Lelija Sočanac. Glottogenesis and Language Conflicts in Europe. Berlin: Logos Verlag, 111-130.

Snell, Julia. 2013. Dialect, interaction and class positioning at school: from deficit to difference to repertoire. Language and Education, 27/2, 110-128.

Spolsky, Bernard. 2004. Language policy: Key topics in sociolinguistics. Cambridge: Cambridge University Press.

Spolsky, Bernard. 2009. Language management. Cambridge: Cambridge University Press.

Starčević, Anđel. 2016. Govorimo hrvatski ili 'hrvatski': standardni dijalekt $\mathrm{i}$ jezične ideologije $\mathrm{u}$ institucionalnom diskursu. Suvremena lingvistika, 81, 67-103.

Starčević, Anđel; Mate Kapović; Daliborka Sarić. 2019. Jeziku je svejedno. Zagreb: Sandorf.

Sujoldžić, Anita. 2009. Viški govori i kulturni identitet mladih na otoku Visu. Ur. Prica, Ines; Željka Jelavić. Destinacije čežnje, lokacije samoće: Uvidi u kulturu i razvojne mogućnosti hrvatskih otoka. Zagreb: Hrvatsko etnološko društvo, 203-220.

Sujoldžić, Anita. 2008. Istrian identities and languages in contact. Suvremena lingvistika, 34/65, 27-56.

Sujoldžić, Anita; Lucija Šimičić. 2013. Public and private language ideologies as reflected in language attitudes on the island of Korčula. Collegium antropologicum, 37/2, 323-334.

Šimičić, Lucija. 2011. Identifikacijski procesi i jezične promjene na otoku Visu. Doktorski rad. Zagreb: Filozofski fakultet Sveučilišta u Zagrebu.

Šimičić, Lucija. 2019. Torn between two nation-states: Agency and power in linguistic identity negotiation in minority contexts. Ur. Glasgow, Gregory Paul; Jeremie Bouchard. Researching agency in language policy and planning. New York - London: Routledge.

Šimičić, Lucija; Klara Bilić Meštrić. 2018. Arbanaški na raskrižju: vitalitet $i$ održivost jednog manjinskog jezika. Zagreb: Srednja Europa.

Šimičić, Lucija; Peter Houtzagers; Anita Sujoldžić; John Nerbonne. 2013. Diatopic Patterning of Croatian Varieties in the Adriatic Region. Journal of Slavic Linguistics, 21/2, 259-301.

Šimičić, Lucija; Anita Sujoldžić. 2004. Cultural Implications of Attitudes and Evaluative Reactions Toward Dialect Variation in Croatian Youth. Collegium antropologicum, 28/1, 97-113.

Škevin Rajko, Ivana; Lucija Šimičić. 2019. Dialect levelling or shift: Lexical outcomes of Štokavian-Čakavian contact in Dalmatia. Ur. Villena- 
Lucija Šimičić, Marija Ćubelić: Između standardnog varijeteta i lokalnih govora...

FILOLOGIJA 76(2021), 201-251

Ponsoda, Juan-Andrés; Francisco Díaz-Montesinos; Antonio-Manuel Ávila-Muñoz; Matilde Vida-Castro. Language Variation - European Perspectives VII: Selected papers from the Ninth International Conference on Language Variation in Europe (ICLaVE 9), Malaga, June 2017, John Benjamins, 204-215. DOI: https://doi.org/10.1075/silv.22.13raj

Težak, Stjepko. 1996. Teorija i praksa nastave hrvatskoga jezika 1. Zagreb: Školska knjiga.

Tollefson, James W. 1991. Planning language, planning inequality: Language policy in the community. London: Longman.

Tollefson, James W.; Miguel Pérez-Milans. 2018. Research and practice in language policy and planning. Ur. Tollefson, James W.; Miguel PérezMilans. The Oxford Handbook of Language Policy and Planning. Oxford: Oxford University Press, 1-32.

Trudgill, Peter. 1975. Accent, dialect and the school. London: Edward Arnold. Tsunoda, Tasaku. 2005. Language Endangerment and Language Revitalization: An Introduction. Berlin - New York: Mouton de Gruyter.

Turza-Bogdan, Tamara. 2009. Stavovi nastavnika o kajkavskome narječju. Hrvatski, 7/1, 173- 192.

Turza-Bogdan, Tamara. 2011. Kajkavsko narječje i književnost u nastavnim planovima i programima. Ur. Bežen, Ante; Đuro Blažeka. I. međimurski filološki dani. Zagreb: Učiteljski fakultet Sveučilišta u Zagrebu, 183-191.

Van De Craen, Pete; Ilse Humblet. 1989. Dialect and Education in Belgium. Ur. Cheshire, Jenny; Viv Edwards; Henk Münstermann; Bert Weltens. Dialect and Education: Some European Perspectives. Clevedon - Philadelphia: Multilingual Matters, 13-29.

Vokić, Denis. 2015. Novi prilozi raspravi o nazivu ukupnog predmeta interesa konzervatorsko-restauratorske i muzejske struke. Godišnjak zaštite spomenika kulture Hroatske, 39, 7-16.

Vuletić, Nikola; Lucija Šimičić. 2018. L'arbënisht all'incrocio tra urbanità e insularità. Ur. Šimičić, Lucija; Ivana Škevin; Nikola Vuletić. Le isole linguistiche dell'Adriatico. Rim - Zadar: Aracne Editore - Sveučilište u Zadru, 143-168.

Vulić, Sanja. 2015. Hrvatski dijalekti i mjesni govori u nastavi. Ur. Suvala, Anđa; Jasna Pandžić. Nestandardni hrvatski jezik prema standardnom hrvatskom jeziku. Zagreb: Agencija za odgoj i obrazovanje, 78-83.

Wei, Li. 2011. Moment analysis and translinguaging space: Discursive construction of identities by multilingual Chinese youth in Britain. Journal of Pragmatics, 43, 1222-1235.

Woolard, Kathryn. 1998. Introduction: Language ideology as a field of inquiry. Ur. Schieffelin, Bambi B.; Katharyn A. Woolard; Paul V. Kro- 
Lucija Šimičić, Marija Ćubelić: Između standardnog varijeteta i lokalnih govora...

FILOLOGIJA 76(2021), 201-251

skrity. Language Ideologies: Practice and Theory. Oxford - New York: Oxford University Press, 3-49.

Yiakoumetti, A. 2007. Choice of classroom language in bidialectal communities: To include or to exclude the dialect? Cambridge Journal of Education, 37/1, 51-66.

Zakon o zaštiti i očuvanju kulturnih dobara. 1999. https://www.zakon. hr/z/340/Zakon-o-za\%C5\%A1titi-i-o\%C4\%8Duvanju-kulturnih-dobara (pristupljeno: 18. 6. 2020.)

Zakon o potvrđivanju Konvencije o zaštiti nematerijalne kulturne baštine. 2005. https://narodne-novine.nn.hr/clanci/medunarodni/2005_06_5_47. html (pristupljeno: 18. 6. 2020.)

\title{
Between the standard variety and local varieties: Language practices of elementary school children in Makarska Coast
}

\begin{abstract}
In the Croatian educational context, a special challenge is teaching the Croatian standard variety in non-Štokavian contexts where children are expected to either master two codes or gradually shift from their native to the standard code, which is often very distant from their first variety at the structural level. Departing from the idea that language policy consists of language ideologies, language practices and language management (Spolsky 2004,2009 ), the aim of the paper is to analyze language practices of primary school students in the Makarska Coast region in formal and informal domains, especially in and out of school, and to determine in what ways language practices are related to attitudes towards standard variety and local speech, i.e. which are the dominant ideologies internalized by Makarska primary school students that influence their attitude towards local speech, frequency and contexts of its use. The analysis of language practices of primary school students is based on the material collected during the field research conducted in 2018 and 2019 in Makarska Coast region. Part of the data was collected by means of a sociolinguistic questionnaire, and part through ethnographic research, which included interviewing teachers as some of the crucial stakeholders in language management process in local contexts.
\end{abstract}

Ključne riječi: Makarsko primorje, upravljanje jezikom, formalno obrazovanje, jezične ideologije, standardni varijetet, lokalni govori

Keywords: Makarska Coast, language management, formal education, language ideologies, standard variety, local varieties 
